This article was published in Journal of Controlled Release, 213, 152-167, 2015

http://dx.doi.org/ 10.1016/j.jconrel.2015.06.034

\title{
Supramolecular Nanoscale Assemblies for Cancer Diagnosis and Therapy
}

Sílvia Castro Coelho ${ }^{1}$, Maria Carmo Pereira ${ }^{1}$, Asta Juzeniene ${ }^{2}$, Petras Juzenas ${ }^{2}$, Manuel A.N. Coelho ${ }^{1, *}$

(1) LEPABE, Department of Chemical Engineering, Faculty of Engineering, University of Porto, Rua Roberto Frias, PT-4200-465 Porto, Portugal

(2)Department of Radiation Biology, Institute for Cancer Research, Radiumhospital, Oslo University Hospital, NO-0310 Oslo, Norway

* corresponding author: Manuel A. N. Coelho

e-mail: mcoelho@,fe.up.pt

\begin{abstract}
Nanocarriers based on polymers, metals and lipids have been extensively developed for cancer therapy and diagnosis due to their ability to enhance drug accumulation in cancer cells and decrease undesired drug toxicity in healthy tissues. Overcoming multidrug resistance by designing proper drug nanocarriers will improve outcome of existing oncologic treatments such as chemotherapy or radiotherapy. In this article the relation between physicochemical properties and capacity of a nanosystem to deliver therapeutic agents into pathological sites is discussed. Most promising examples of drug delivery systems are reviewed, and, in particular, the design of a carbohydrate based matrix with entrapped gold nanoparticles is highlighted.
\end{abstract}

Keywords: chemotherapy, drug delivery systems, gold nanoparticles, polymeric nanoparticles, internalization, radiotherapy

\section{Introduction}

Based on GLOBOCAN estimates, about 3.4 million new cancer cases and 1.8 million deaths due to cancer occurred in 2012 in Europe (Figure 1) (Non-melanoma skin cancer is not included). Breast, colorectal, lung and prostate cancers are the most common types of cancer. Lung cancer is the leading cause of death contributing to nearly $20 \%$ of all cancers deaths. Other leading causes of cancer death include colorectal, breast and stomach cancers. Ratio of reported deaths (mortality) due to new cases (incidence) is calculated for 27 types of cancer (Figure 1). The higher ratio is associated with a high risk of death, and a lower number is associated with a lower risk of death. Testicular, thyroid, prostate and breast cancer have relatively good prognosis (ratio $<0.3$ ). Patients with ovarian, gallbladder, brain, stomach, lung or oesophageal cancer have quite poor prognosis (ratio 0.5-0.9). While patients with pancreatic or liver cancer have the worst prognosis of all malignancies (ratio 1). This means that conventional therapies (surgery, radiotherapy and chemotherapy) and modern treatment modalities (immunotherapy, biologic response modifiers, differentiating drugs, antiangionesis drugs, signal transduction inhibitors, vaccines, targeted therapy, 
hormonal therapy, gene therapy) are not effective enough to treat all cancers. Often it has been found that promising agents in vitro have had little impact on disease in clinical trials [1]. One of the main causes behind the failure of treatments are the development of various resistance mechanisms by cancer cells leading to the recurrence of the disease [2]. The heterogeneity of molecular alterations in signalling pathways involved in the pathogenesis of these tumours contributes significantly to their resistance to treatment.

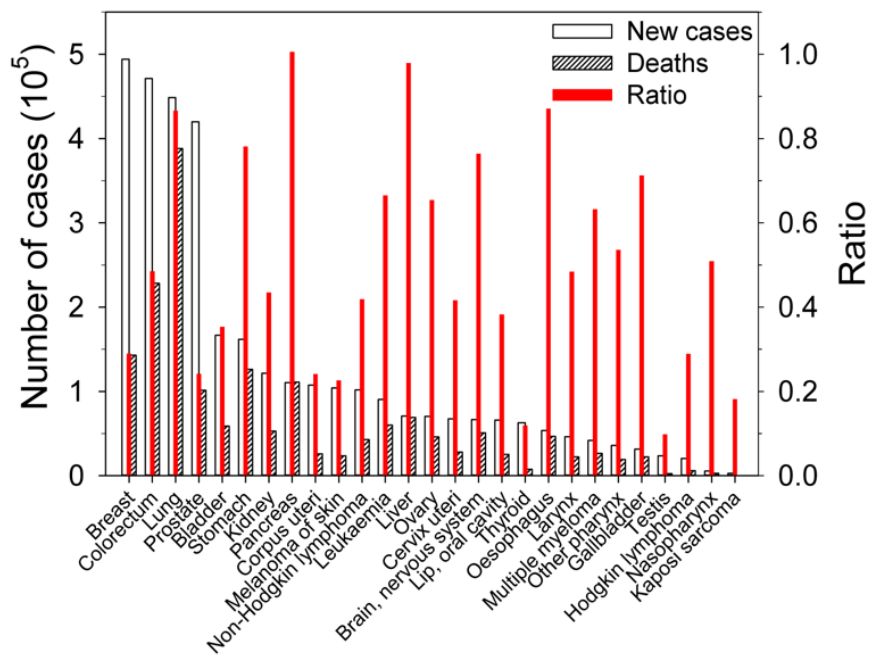

Figure 1. Number of new cases and deaths from cancer for both sexes and all ages in Europe in 2012 [3]. Higher ratio is associated with higher risk of death from cancer.

Chemotherapeutic agents used in cancer treatment are capable of blocking critical cell cycle phases leading to death of tumour cells (Table 1) [4].

Table 1. List of Chemotherapeutic agents $[4,5]$.

\begin{tabular}{|c|c|c|}
\hline $\begin{array}{c}\text { Type of Chemotherapeutic } \\
\text { agents }\end{array}$ & $\begin{array}{l}\text { Class of Chemotherapeutic } \\
\text { agents }\end{array}$ & Examples \\
\hline \multirow{5}{*}{ Alkylating agents } & Mustard gas derivative & $\begin{array}{l}\text { Mechlorethamine } \\
\text { Cyclophosphamide } \\
\text { Chlorambucil } \\
\text { Melphalan } \\
\text { Ifosfamide }\end{array}$ \\
\hline & Ethylenimines & $\begin{array}{l}\text { Thiotepa } \\
\text { Hexamethylmelamine }\end{array}$ \\
\hline & Alkylsulfonates & Busulfan \\
\hline & Hydrazines and Triazines & $\begin{array}{l}\text { Altretamine } \\
\text { Procarbazine } \\
\text { Dacarbazine } \\
\text { Temozolomide }\end{array}$ \\
\hline & Nitrosureas & $\begin{array}{l}\text { Carmustine } \\
\text { Lomustine } \\
\text { Streptozocin }\end{array}$ \\
\hline
\end{tabular}




\begin{tabular}{|c|c|c|}
\hline & Metal salts & $\begin{array}{l}\text { Carboplatin } \\
\text { Cisplatin } \\
\text { Oxaliplatin }\end{array}$ \\
\hline \multirow[t]{3}{*}{ Antitumour antibiotics } & Anthracyclines & $\begin{array}{l}\text { Doxorubicin } \\
\text { Daunorubicin } \\
\text { Epirubicin } \\
\text { Mitoxantrone } \\
\text { Idarubicin } \\
\end{array}$ \\
\hline & Chromomycins & $\begin{array}{l}\text { Dactinomycin } \\
\text { Plicamycin }\end{array}$ \\
\hline & Miscellaneous & $\begin{array}{l}\text { Mitomycin } \\
\text { Bleomycin }\end{array}$ \\
\hline \multirow{3}{*}{ Antimetabolites } & Pyrimidine antagonist & $\begin{array}{l}\text { Methotrexate } \\
\text { 5-Fluorouracil } \\
\text { Foxuridine } \\
\text { Cytarabine } \\
\text { Capecitabine } \\
\text { Gemcitabine }\end{array}$ \\
\hline & Purine antagonist & $\begin{array}{l}\text { 6-Mercaptopurine } \\
\text { 6-Thioguanine }\end{array}$ \\
\hline & Adenosine deaminase inhibitor & $\begin{array}{l}\text { Cladribine } \\
\text { Fludarabine } \\
\text { Nelarabine } \\
\text { Pentostatin } \\
\end{array}$ \\
\hline \multirow{4}{*}{ Plant alkaloids } & Vinca alkaloids & $\begin{array}{l}\text { Vincristine } \\
\text { Vinblastine } \\
\text { Vinorelbine }\end{array}$ \\
\hline & Podophyllotoxins & $\begin{array}{l}\text { Etoposide } \\
\text { Tenisopide }\end{array}$ \\
\hline & Taxanes & $\begin{array}{l}\text { Paclitaxel } \\
\text { Docetaxel }\end{array}$ \\
\hline & Camptothecan analogs & $\begin{array}{l}\text { Irinotecan } \\
\text { Topotecan }\end{array}$ \\
\hline \multirow[b]{2}{*}{ Topoisomerase inhibitors } & Topoisomerase I inhibitors & $\begin{array}{l}\text { Ironotecan } \\
\text { topotecan }\end{array}$ \\
\hline & Topoisomerase II inhibitors & $\begin{array}{l}\text { Amsacrine } \\
\text { Etoposide } \\
\text { etoposide phosphate } \\
\text { teniposide }\end{array}$ \\
\hline \multirow{4}{*}{ Miscellaneous Antineoplastics } & $\begin{array}{ll}\text { Ribonucleotide } & \text { reductase } \\
\text { inhibitor } & \end{array}$ & Hydroxyurea \\
\hline & Adrenocortical steroid inhibitor & Mitotane \\
\hline & Enzymes & $\begin{array}{l}\text { Asparaginase } \\
\text { Pegaspargase }\end{array}$ \\
\hline & Antimicrotubule agent & Estramustine \\
\hline
\end{tabular}




\begin{tabular}{cll}
\hline & & Bexarotene \\
& Retinoids & $\begin{array}{l}\text { Isotretinoin } \\
\text { Tretinoin }\end{array}$ \\
\hline \multirow{3}{*}{$\begin{array}{c}\text { Mitotic inhibitors (plant } \\
\text { alkaloids and natural products) }\end{array}$} & Taxanes & Paclitaxel \\
\cline { 2 - 3 } & & Docetaxel \\
\cline { 2 - 3 } & Epothilones & ixabepilone \\
\cline { 3 - 3 } & Vinca alkaloids & Vinblastine \\
& & Vincristine \\
Corticosteroids & & vinorelbine \\
\hline \multirow{2}{*}{ Others } & & Estramustine \\
\hline & & Prednisone \\
& & Methylprednisolone \\
& & Dexamethasone \\
\hline
\end{tabular}

However, chemotherapy success rate has limitations due to undesired side effects and variations in individual patient responses. Anticancer activity of chemotherapeutics is not selective to tumours often causing damage to healthy tissues [4, 6-8]. Unfavourable drug pharmacokinetics (low half-life time in the bloodstream) and pharmacodynamics (unselective drug-receptor interactions) combined with high drug doses and poor drug solubility are the principal limitations of conventional chemotherapy [7, 9-12]. In cancer treatment, there are challenges in design and optimization of a synergism among different therapeutic components and a myriad of drugs to conquer the above mentioned limitations. Thus, there is a need for innovative medical treatment strategies effective even for advanced disease. Nanotechnology represents an innovative direction offering many advantages for cancer detection and treatment.

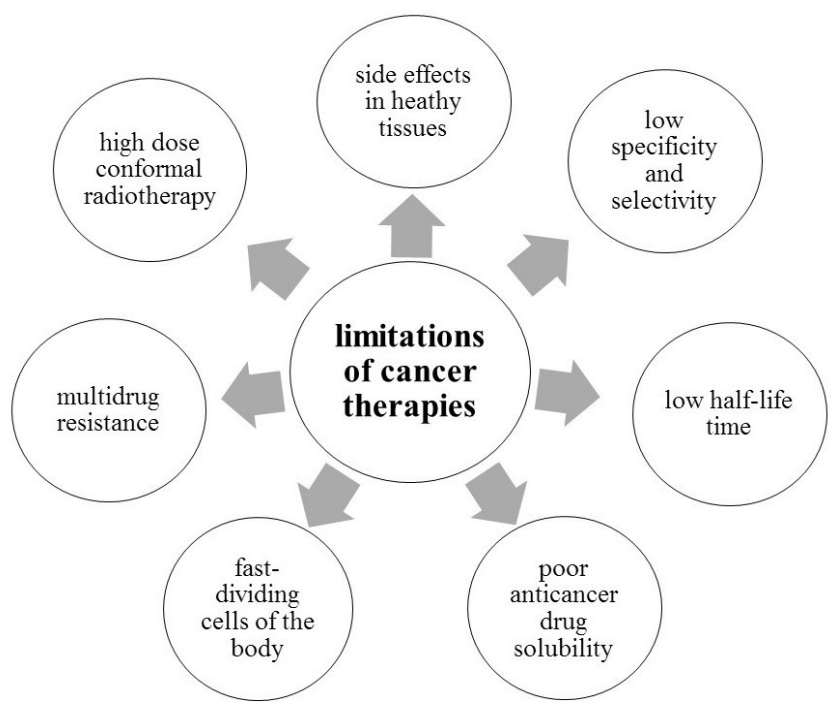

Scheme 1. Most common drawbacks of the current cancer therapies. 


\section{Challenges for new delivery systems}

\section{- Angiogenesis}

Solid tumours have particular pathophysiological characteristics such as rapid abnormal formation of new capillary blood vessels (angiogenesis) [13, 14] revealing hyper vascular permeability, defective vascular architecture and poor lymphatic drainage compared to that of normal tissues $[13,15]$ (Figure 2). Angiogenesis process is regulated by the production of pro-angiogenic cytokines, matrix proteins, growth factors and other mediators $[16,17]$. In fact, these angiogenesis activators and inhibitors are the main targets of current clinical investigations to improve treatment of carcinomas [16]. Development of tumour vasculature from pre-existing vessels is fundamental for the growth and progression of cancer. Particularly, vascular endothelial growth factor (VEGF, also known as vascular permeability factor, VPF) has been investigated as a prominent cytokine in the angiogenesis mechanism [18].

In general, administration of effective concentrations of anti-angiogenic agents for a long period is not possible due to dose-limiting systemic toxicity to non-malignant tissues [19, 20]. This fact is improved by a weakened pharmacokinetics [21]. A low selectivity of anticancer agents which are, normally, toxic to healthy cells and the high fraction of cancer cell mutation contributes to a low chemotherapeutic process [21]. This fact occurs due to the drug resistance associated with changes in changes in drug metabolism, changes in survival/apoptotic pathways or amplification of drug targets $[22,23]$. On the other hand, some studies reported the intratumoural heterogeneity, due to genetic variation, stochastic processes, the microenvironment, cell and tissue plasticity, that will have effect on drug sensitivity [22, 24, 25]. Heterogeneity varies between and within tumour types [26]. A long circulation time and bioavailability of an anti-angiogenic drug and, consequently, the minimization of drug loss and administration of a lower drug dose with fewer treatment sessions could be a strategy to target the drug in the direction of a specific tissue, improving the treatment response and lessen side effects $[19,27]$.

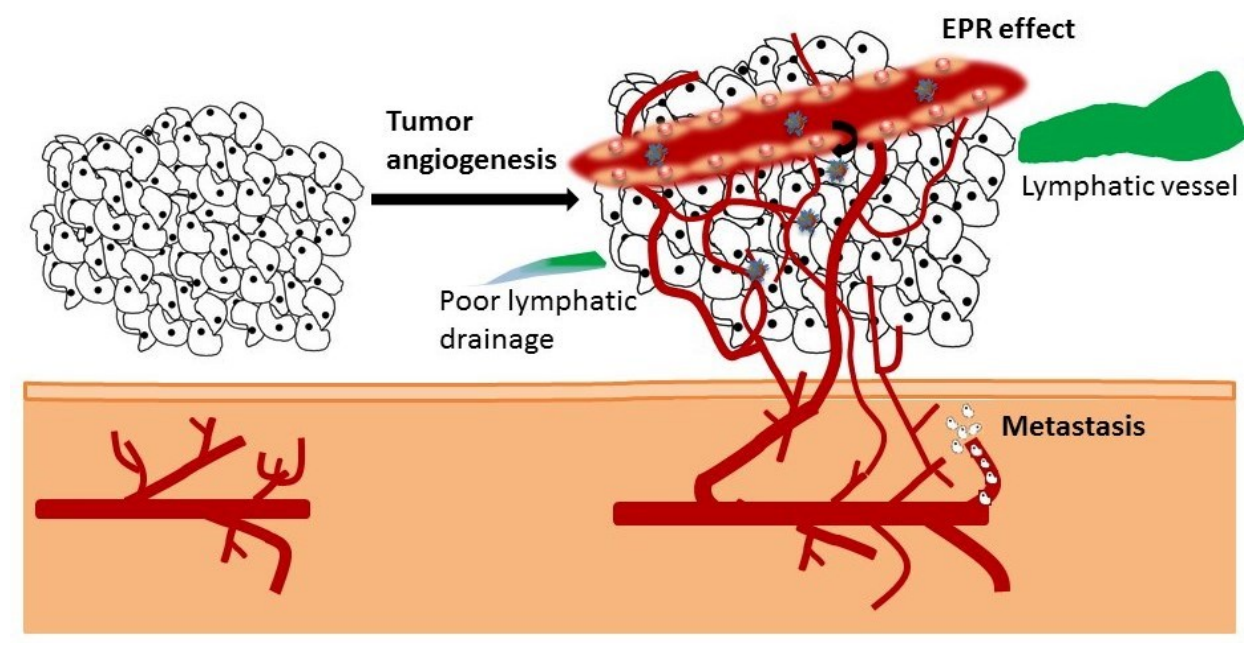

Figure 2. Schematic illustration of angiogenesis process.

- Multidrug Resistance

A factor correlating with angiogenesis process is the multidrug resistance (MDR) problem $[28,29]$ in conventional chemotherapy. It is well known that cancer cells divide and grow 
much faster than other cells in the body. This rapid uncontrolled proliferation induces frequent mutations leading to the development of resistance against anticancer therapy. MDR of cancer cells severely limits therapeutic outcomes [30,31]. Cancer drug resistance is a complex phenomenon (Figure 3) that is influenced by drug inactivation, drug target alteration, drug efflux, DNA damage repair, cell death inhibition, epithelial-mesenchymal transition, inherent cell heterogeneity, epigenetic effects, or any combination of these mechanisms $[30,31]$.

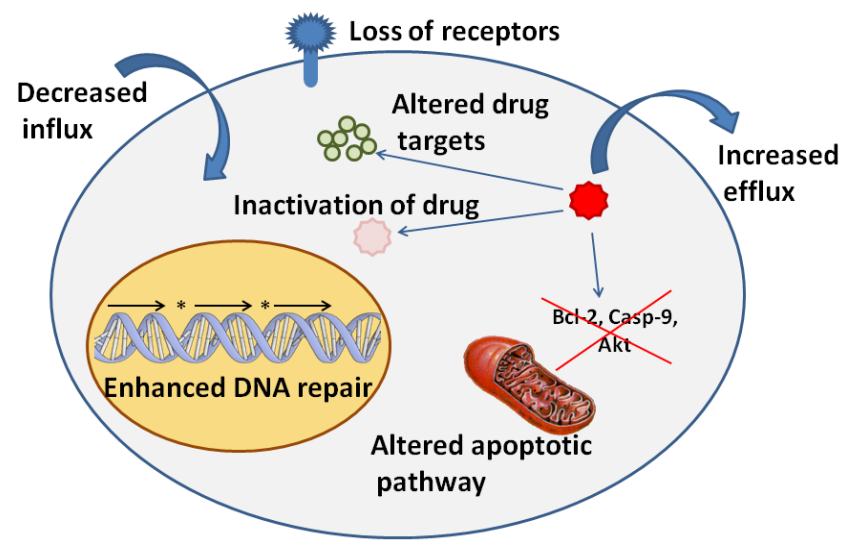

Figure 3. Cellular factors that may cause drug resistance. These mechanisms can act independently or in combination through various signal transduction pathways.

Overexpression of the ATP-dependent pumps, such as P-glycoprotein, promotes MDR. Limitations associated to the drug influx occur followed by increased elimination of the drug from the cancer cells $[32,33]$. Overall, MDR mechanism is a concert of factors such as decrease of drug uptake, increase of drug efflux, activation of DNA repair processes and other adaptive molecular responses within the nucleus or cytoplasm [34]. Cellular membrane provides one of the most frequent defence mechanisms involving a permeability P-glycoprotein, also known as MDR protein. P-glycoprotein decreases the influx of an anticancer agent and is also responsible for the drug efflux out of solid tumours changing the mutation and apoptotic mechanism [7]. In modern anticancer therapy it is essential not only to let the protection mechanism of cancer cells to fail but also to protect non-tumour cells from the toxic effects of the chemotherapeutic agents [28, 29]. Many strategies to overcome such resistance have been suggested, and nanoparticle technologies may enhance drug delivery and activity to overcome some resistance mechanisms.

\section{Drug Delivery Systems}

In the last years, drug delivery systems (DDS) have attracted a considerable attention as promising tools to achieve better drug retention and release in cancer tissues and, thus, to overcome the MDR and associated side effects. DDS have impact in therapeutics and diagnostics applications due to their unique electrical, chemical and optical characteristics, biocompatibility and reactive surface, which confer high potential to improved drug bioavailability, drug controlled release, favourable pharmacologic and pharmacodynamic properties and significant reduction of unwanted systemic side effects $[6,8,11,35]$. 
Targeting anticancer drugs selectively to cancer cells is a concurrent challenge of nanotechnology-based DDS [36, 37]. Transport and release of the anticancer drug at a specific site by NPs will give considerable improvement of cancer treatment (Figure 4) [32].

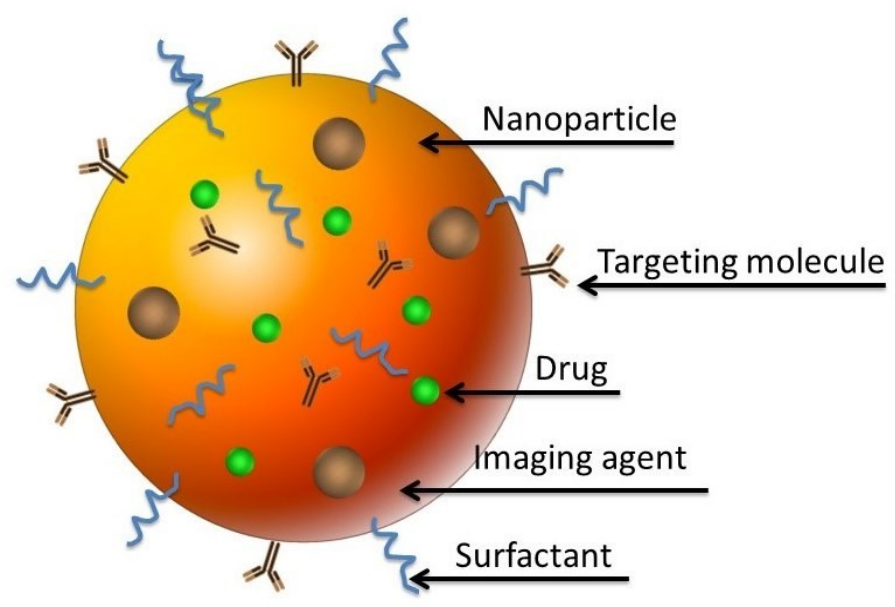

Figure 4. Drug delivery nanosystem.

Nitrosylcobalamin has been shown to act as a "Trojan horse" to deliver nitric oxide (NO) to cancer cells. Once NO is liberated in the cells it inhibits methionine synthase leading to cell death [38]. This suggests the role of NO in enhancing the EPR-mediated drug release opening a new direction in exploring the combination of drugs and NO [39]. Controlled release of anticancer drugs by ionizing radiation has not been shown so far in a clinical situation. However, drug release from biodegradable polymer nanoparticles has been reported in cell models. Release of lipophilic (lidocaine base) and hydrophilic (lidocaine salt) model drugs has been shown from PLGA nanoparticles [40]. Other investigators have reported doxorubicin release from gold nanoparticles by radiation [41]. Drugs controlling proteasome activity are also suited for manipulation of cell sensitivity to radiation [42]. We have shown that uptake and action of the proteasome inhibitor drug (bortezomib) is enhanced by gold nanoparticles [43] and the combination of gold nanoparticles and radiation [44].The main effect responsible for polymer nanoparticle/micelle disintegration is polymer chain split due to ionizing radiation [45]. Assembling magnetite (iron oxide) and gold NPs could be an attractive way to design novel contrast agents for dual magnetic resonance imaging (MRI) / X-ray detection [46] and MRI / photooptical imaging [47]. Hybrids made of iron oxide NPs with gold can also be a unique platform for magnetothermal drug delivery and therapy [48].

A broad choice of materials is available for formulation of DDS to improve drug bioavailability and efficacy. The main challenges of DDS are biocompatibility, crossing biological barriers and targeting the specific sites. The present approaches to overcome these drawbacks are based in the development of DDS based in natural polymers, biocompatible metals and purification methods. Additionally new approaches based in fluorescent labelled DDS are used for identification of dysplasia by molecular imaging [49]. The prof-of-principle of targeting and drug release is being investigated by attaching 
antibodies to DDS [50] and by applying radiation $[51,52]$ or by thermal effects in the tissues $[53,54]$.

Nanosystems like dendrimers, liposomes, niosomes, metal based NPs, micelles, nanoemulsions, quantum dots and polymer NPs have been developed (Table 2). They are expected to overcome the limitations such as poor solubility and stability at physiological $\mathrm{pH}$, inadequate biodistribution, low bioavailability, which are observed when anticancer drugs are administered in a conventional way [4, 9, 10, 32, 36, 55-58]. Physico-chemical properties such as composition, shape, roughness, hydrophobicity or hydrophilicity, hydrodynamic diameter and surface charge influence the stability of DDS nanosystems [12, $59]$ and their drug delivery applications $[8,60]$.

Table 2. DDS nanosystem classes and their composition.

\begin{tabular}{|c|c|c|c|c|}
\hline Nanosystem & & $\begin{array}{l}\text { Schematic } \\
\text { representation }\end{array}$ & Size & $\begin{array}{l}\text { The newest } \\
\text { reviews }\end{array}$ \\
\hline Dendrimers & Poly(amidoamine) & & $1-10 \mathrm{~nm}$ & {$[61-65]$} \\
\hline Fullerenes & $\begin{array}{l}\text { Carbon based } \\
\text { nanocarriers }\end{array}$ & & & {$[66]$} \\
\hline \multirow[t]{3}{*}{$\begin{array}{l}\text { Inorganic } \\
\text { nanoparticles }\end{array}$} & $\begin{array}{l}\text { Gold nanoparticles } \\
\text { (AuNPs) }\end{array}$ & & $2-100 \mathrm{~nm}$ & {$[67-72]$} \\
\hline & Quantum dots & & $1-20 \mathrm{~nm}$ & {$[73-78]$} \\
\hline & Carbon nanotubes & & $\begin{array}{l}\text { Length of } \\
140 \mathrm{~nm}\end{array}$ & {$[79-84]$} \\
\hline
\end{tabular}




\begin{tabular}{|c|c|c|c|c|}
\hline Nanosystem & & $\begin{array}{l}\text { Schematic } \\
\text { representation }\end{array}$ & Size & $\begin{array}{l}\text { The newest } \\
\text { reviews }\end{array}$ \\
\hline & $\begin{array}{l}\text { Mesoporous silica } \\
\text { nanoparticles }\end{array}$ & 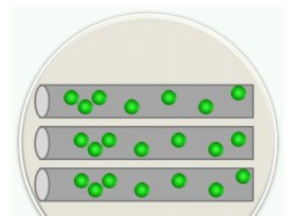 & $80-500 \mathrm{~nm}$ & {$[85-91]$} \\
\hline $\begin{array}{l}\text { Polymer-based } \\
\text { nanoparticles }\end{array}$ & $\begin{array}{l}\text { Polylactic acid (PLA) } \\
\text { nanoparticles; } \\
\text { poly(cyano)-acrylates, } \\
\text { polyethyleneimine; } \\
\text { polysaccharides including } \\
\text { alginate, chitosan, gum } \\
\text { Arabic }\end{array}$ & & & [92-97] \\
\hline Liposomes & Phospholipids & & $50-210 \mathrm{~nm}$ & [98-100] \\
\hline
\end{tabular}

Nanosystems can be functionalized to attach drugs and targeting biomolecules [101]. It is reported that some nanosystems based on AuNPs, polymeric NPs (FDA approved) and liposomes show low cytotoxicity and good biocompatibility required to preserve the pharmacokinetic and pharmacodynamic properties of drug molecules [101]. On the other hand, there are some drawbacks associated with the nanoparticles. The nanoparticle physical aggregation in liquid and dry forms can set limitations for their handling and applicability [102]. Additionally, in vivo efficacy should be evaluated [103]. DDS may be administered by different routes, which include intravenous, intramuscular or subcutaneous injection, as well as per oral, ophthalmic or transdermal administration [104]. In some cases, it may be combined with surgical intervention for DDS-guided cancer removal.

Continuous research has been focused on the behaviour of nanostructures in biological systems. When nanocarriers are administered an immune response is triggered in order to protect the body against the foreign NPs. It has been shown that relatively small NPs can avoid being detected and cleared by the immune system involving reticuloendothelial system (RES) and opsonization process $[105,106]$. Intravenous administration of NPs leads to their recognition by the immune system and, consequently, phagocytosis occurs. Hence, it is important to decrease the adsorption of blood components such as opsonins on the NP surface, thus, hiding the drug from phagocytic cells [107]. Improvement of DDS stability and bioavailability can be achieved by functionalizing NPs with hydrophilic polymers/surfactants such as poly(ethylene glycol) layer, poloaximine and polysorbate 80 
$[7,12,108]$. Effective repulsive forces will avoid aggregation and precipitation of such polymer-functionalized nanocarriers prolonging their blood circulation time $[7,12,60]$. For specific cell targeting other functionalization methods are being developed by conjugation of NPs with specific ligands or therapeutic agents. Auspicious utilization of chimeric and humanized antibodies as targeting agents opens up a possibility for successful application of nanosystems as targeting and selective DDS for anticancer drug delivery [109].

Efficient loading of chemotherapeutic agents, such as doxorubicin, paclitaxel, carboplatin, into NPs has been reported [110-114]. Several colloidal carriers are under development or already on the market (Table 3).

Table 3. Colloidal systems under development, in clinical trials or on the market

\begin{tabular}{|c|c|c|c|c|c|}
\hline Formulation & Drug & Product & Application & Status & References \\
\hline \multirow{4}{*}{$\begin{array}{l}\text { PEGylated } \\
\text { liposome }\end{array}$} & \multirow{7}{*}{ Doxorubicin } & \multirow{4}{*}{ Doxil } & $\begin{array}{l}\text { Ovarian and } \\
\text { multiple } \\
\text { myeloma }\end{array}$ & $\begin{array}{l}\text { Phase I- } \\
\text { II }\end{array}$ & $\begin{array}{l}\text { https://clinicaltrials.gov/ct2/show/N } \\
\text { CT02081495?term=Doxil\&rank=1 } \\
\text { https://clinicaltrials.gov/ct2/show/N } \\
\text { CT00826085?term=Thermodox\&ra } \\
\text { nk=1 } \\
\text { https://clinicaltrials.gov/ct2/show/N } \\
\text { CT01715168?term=Doxil\&rank=5 }\end{array}$ \\
\hline & & & $\begin{array}{c}\text { Acute } \\
\text { Myeloid } \\
\text { Leukemia }\end{array}$ & Phase II & $\begin{array}{l}\text { https://clinicaltrials.gov/ct } 2 / \text { show } / \mathrm{N} \\
\text { CT01736943?term=Doxil\&rank=13 }\end{array}$ \\
\hline & & & $\begin{array}{l}\text { Relapsed or } \\
\text { Refractory } \\
\text { Cutaneous } \\
\text { T-cell } \\
\text { Lymphoma }\end{array}$ & Phase I & $\begin{array}{l}\text { https://clinicaltrials.gov/ct2/show } / \mathrm{N} \\
\text { CT01902225?term=Doxil\&rank=19 }\end{array}$ \\
\hline & & & $\begin{array}{l}\text { breast } \\
\text { cancer }\end{array}$ & Phase I & $\begin{array}{l}\text { https://clinicaltrials.gov/ct2/show/N } \\
\text { CT01902225?term=Doxil\&rank=19 } \\
\text { https://clinicaltrials.gov/ct2/show/N } \\
\text { CT02131506?term=Doxil\&rank=55 }\end{array}$ \\
\hline \multirow{3}{*}{ Lipsomes } & & \multirow{3}{*}{ Thermodox } & $\begin{array}{l}\text { Primary } \\
\text { liver }\end{array}$ & Phase III & $\begin{array}{l}\text { http://celsion.com/docs/pipeline_ov } \\
\text { erview } \\
\text { https://clinicaltrials.gov/ct2/show/N } \\
\text { CT00346229?term=ThermoDox\&ra } \\
\text { nk=8 }\end{array}$ \\
\hline & & & $\begin{array}{l}\text { breast } \\
\text { cancer }\end{array}$ & $\begin{array}{l}\text { Phase I- } \\
\text { II }\end{array}$ & $\begin{array}{l}\text { http://celsion.com/docs/pipeline_ov } \\
\text { erview } \\
\text { https://clinicaltrials.gov/ct2/show/N } \\
\text { CT00826085?term=Thermodox\&ra } \\
\text { nk=1 }\end{array}$ \\
\hline & & & $\begin{array}{c}\text { Liver } \\
\text { metastases }\end{array}$ & Phase I & $\begin{array}{l}\text { http://celsion.com/docs/pipeline ov } \\
\text { erview }\end{array}$ \\
\hline
\end{tabular}




\begin{tabular}{|c|c|c|c|c|c|}
\hline & & & & & $\begin{array}{l}\text { https://clinicaltrials.gov/ct2/show/N } \\
\text { CT02181075?term=Thermodox\&ra } \\
\text { nk=4 }\end{array}$ \\
\hline $\begin{array}{l}\text { Polymeric } \\
\text { micelles (PEG- } \\
\text { poly(aspartic } \\
\text { acid) block } \\
\text { copolymer) }\end{array}$ & & NK911 & $\begin{array}{l}\text { Solid } \\
\text { tumours in } \\
\text { mice }\end{array}$ & Phase I & $\begin{array}{l}\text { http://www.ncbi.nlm.nih.gov/pubm } \\
\text { ed/15477860 }\end{array}$ \\
\hline \multirow{6}{*}{$\begin{array}{c}\text { Albumin } \\
\text { nanoparticles }\end{array}$} & \multirow{8}{*}{ Paclitaxel } & \multirow{6}{*}{ Abraxane } & $\begin{array}{l}\text { Advanced } \\
\text { breast, } \\
\text { advanced } \\
\text { non-small } \\
\text { lung and } \\
\text { advanced } \\
\text { pancreatic } \\
\text { cancers }\end{array}$ & $\begin{array}{l}\text { On the } \\
\text { market }\end{array}$ & $\begin{array}{l}\text { http://www.abraxane.com/ } \\
\text { http://chemocare.com/chemotherap } \\
\text { y/drug- } \\
\text { info/abraxane.aspx\#.VIcb2jGsUxQ }\end{array}$ \\
\hline & & & $\underline{\text { Multiple }}$ & $\begin{array}{l}\text { Phase I- } \\
\text { II }\end{array}$ & $\begin{array}{l}\text { https://clinicaltrials.gov/ct2/show/N } \\
\text { CT02075021?term=Abraxane\&rank } \\
\text { ht } \\
\text { https://clinicaltrials.gov/ct2/show/N } \\
\text { CT02075021?term=Abraxane\&rank } \\
=4\end{array}$ \\
\hline & & & $\begin{array}{l}\text { Metastatic } \\
\text { pancreatic } \\
\text { cancer }\end{array}$ & Phase II & $\begin{array}{l}\text { https://clinicaltrials.gov/ct2/show } / \mathrm{N} \\
\text { CT02017015?term=abraxane\&rank } \\
=5\end{array}$ \\
\hline & & & $\begin{array}{l}\text { Metastatic } \\
\text { Melanoma }\end{array}$ & Phase II & $\begin{array}{l}\text { https://clinicaltrials.gov/ct } 2 / \text { show } / \mathrm{N} \\
\text { CT01827111?term=abraxane\&rank } \\
=8\end{array}$ \\
\hline & & & $\begin{array}{l}\text { Colorectal } \\
\text { and Small } \\
\text { Bowel } \\
\text { Adenocarcin } \\
\text { o)mas }\end{array}$ & Phase II & $\begin{array}{l}\text { https://clinicaltrials.gov/ct2/show/N } \\
\text { CT01730586?term=abraxane\&rank } \\
=9 \\
\text { https://clinicaltrials.gov/ct2/show/N } \\
\text { CT02103062?term=abraxane\&rank } \\
=58\end{array}$ \\
\hline & & & $\begin{array}{l}\text { Recurrent } \\
\text { and } \\
\text { Refractory } \\
\text { Lymphoma }\end{array}$ & $\begin{array}{l}\text { Phase I- } \\
\text { II }\end{array}$ & $\begin{array}{l}\text { https://clinicaltrials.gov/ct2/show/N } \\
\text { CT01555853?term=abraxane\&rank } \\
=22\end{array}$ \\
\hline \multirow{2}{*}{$\begin{array}{c}\text { Polymeric } \\
\text { micelles } \\
\text { (poly(ethylene } \\
\text { glycol)- } \\
\text { poly(D,L- } \\
\text { lactide) } \\
\text { copolymer) }\end{array}$} & & \multirow[t]{2}{*}{ Genexol-PM } & $\begin{array}{l}\text { Non-small } \\
\text { Lung and } \\
\text { breast } \\
\text { cancer }\end{array}$ & $\begin{array}{l}\text { On the } \\
\text { market }\end{array}$ & $\begin{array}{l}\text { http://www.evaluategroup.com/Uni } \\
\frac{\text { versal/View.aspx? type }=\text { Story \&id }=2}{[115]}\end{array}$ \\
\hline & & & $\begin{array}{l}\text { Advanced } \\
\text { malignancie } \\
\text { S }\end{array}$ & Phase I & $\begin{array}{l}\text { http://www.ncbi.nlm.nih.gov/pubm } \\
\text { ed/15173077 }\end{array}$ \\
\hline
\end{tabular}




\begin{tabular}{|c|c|c|c|c|c|}
\hline & & & $\begin{array}{l}\text { Advanced } \\
\text { breast } \\
\text { Cancer }\end{array}$ & Phase II & $\begin{array}{l}\text { https://clinicaltrials.gov/ct2/show/N } \\
\text { CT01784120?term=Genexol- } \\
\text { PM\&rank=7 }\end{array}$ \\
\hline & & & $\begin{array}{l}\text { Locally } \\
\text { Advanced } \\
\text { Head and } \\
\text { Neck Cancer }\end{array}$ & Phase II & $\begin{array}{l}\text { https://clinicaltrials.gov/ct2/show } / \mathrm{N} \\
\text { CT01689194?term=Genexol- } \\
\text { PM\&rank=8 }\end{array}$ \\
\hline $\begin{array}{l}\text { Cetyl alcohol/ } \\
\text { polysorbate } \\
\text { nanoparticles }\end{array}$ & & & $\begin{array}{l}\text { Brain } \\
\text { tumours: U- } \\
118, \text { HCT- } \\
15 \text { cells }\end{array}$ & $\begin{array}{l}\text { Under } \\
\text { develop } \\
\text { ment }\end{array}$ & [116] \\
\hline PEGAuNPs & $\begin{array}{l}\text { Human tumour } \\
\text { necrosis factor } \\
\text { alpha, TNF }\end{array}$ & $\begin{array}{l}\text { Aurimmune } \\
\text { (CYT-6091) }\end{array}$ & $\begin{array}{l}\text { Advanced } \\
\text { Solid } \\
\text { Tumours }\end{array}$ & Phase I & {$[117]$} \\
\hline Liposomes & Uridine & & $\begin{array}{l}\text { Metastatic } \\
\text { solid tumour }\end{array}$ & Phase I & [118] \\
\hline & & & $\begin{array}{l}\text { Advanced } \\
\text { and } \\
\text { Metastatic } \\
\text { Pancreatic } \\
\text { Cancer }\end{array}$ & $\begin{array}{l}\text { Phase I- } \\
\text { II }\end{array}$ & $\begin{array}{l}\text { https://clinicaltrials.gov/ct2/show/st } \\
\text { udy/NCT00910741?term=NC- } \\
\text { 6004\&rank=3 }\end{array}$ \\
\hline micelles & Cisplatin & NC-6004 & $\begin{array}{c}\text { Solid } \\
\text { cancer, } \\
\text { Pancreatic } \\
\text { and non- } \\
\text { small lung } \\
\text { cancers }\end{array}$ & $\begin{array}{l}\text { Under } \\
\text { develop } \\
\text { ment }\end{array}$ & $\begin{array}{l}\text { http://www.nanocarrier.co.jp/en/res } \\
\text { earch/pipeline/02.html }\end{array}$ \\
\hline $\begin{array}{c}\text { Polymeric } \\
\text { nanoparticles }\end{array}$ & Docetaxel & $\begin{array}{l}\text { Docetaxel- } \\
\text { PNP }\end{array}$ & $\begin{array}{l}\text { Advanced } \\
\text { solid } \\
\text { malignancie } \\
\text { s }\end{array}$ & Phase I & $\begin{array}{l}\text { http://clinicaltrials.gov/ct2/show/N } \\
\text { CT01103791 }\end{array}$ \\
\hline \multirow{3}{*}{ Liposomes } & \multirow{3}{*}{ Amphotericin B } & \multirow{3}{*}{ AmBisome } & $\begin{array}{l}\text { Fungal } \\
\text { infections }\end{array}$ & $\begin{array}{l}\text { On the } \\
\text { market }\end{array}$ & $\begin{array}{l}\text { https://www.ambisome.com/ } \\
\text { Gilead Sciences }\end{array}$ \\
\hline & & & $\begin{array}{c}\text { Acute } \\
\text { Leukaemia }\end{array}$ & Phase II & $\begin{array}{l}\text { https://clinicaltrials.gov/ct2/show } / \mathrm{N} \\
\text { CT01615809?term=AmBisome\&ra } \\
\text { nk=7 }\end{array}$ \\
\hline & & & $\begin{array}{c}\text { visceral } \\
\text { leishmaniasi } \\
\text { s in HIV co- } \\
\text { infected } \\
\text { Ethiopian } \\
\text { patients }\end{array}$ & Phase III & $\begin{array}{l}\text { https://clinicaltrials.gov/ct2/show/N } \\
\underline{\text { CT02011958?term=AmBisome\&ra }} \\
\underline{\mathrm{nk}=5}\end{array}$ \\
\hline
\end{tabular}




\begin{tabular}{|c|c|c|c|c|c|}
\hline & & & $\begin{array}{l}\text { advanced } \\
\text { HIV } \\
\text { infection }\end{array}$ & $\begin{array}{l}\text { Phase I- } \\
\text { II }\end{array}$ & $\begin{array}{l}\text { https://clinicaltrials.gov/ct2/show } / \mathrm{N} \\
\text { CT00885703?term=AmBisome\&ra } \\
\text { nk=84 }\end{array}$ \\
\hline \multirow{3}{*}{ nanocrystals } & $\begin{array}{l}\text { paclitaxel and } \\
\text { camptothecin }\end{array}$ & & $\begin{array}{c}\text { human lung } \\
\text { cancer and } \\
\text { murine } \\
\text { breast } \\
\text { cancer }\end{array}$ & \multirow{3}{*}{$\begin{array}{l}\text { Under } \\
\text { develop } \\
\text { ment }\end{array}$} & [119] \\
\hline & $\begin{array}{l}1 \text { platinum } \\
\text { anticancer drug } \\
S\end{array}$ & & $\begin{array}{c}\text { human } \\
\text { cervical } \\
\text { cancer HeLa } \\
\text { cells and the } \\
\text { human } \\
\text { hepatocarcin } \\
\text { oma HepG2 } \\
\text { cells }\end{array}$ & & [120] \\
\hline & paclitaxel & & $\begin{array}{c}\text { Developmen } \\
\text { t of } \\
\text { Multifunctio } \\
\text { nal Hybrid } \\
\text { Nanocrystal } \\
\text { s for Cancer } \\
\text { Therapy and } \\
\text { Diagnosis }\end{array}$ & & {$[121]$} \\
\hline nanoparticles & FUS1 & $\begin{array}{l}\text { FUS1- } \\
\text { nanoparticles }\end{array}$ & Lung cancer & Phase IV & $\begin{array}{l}\text { https://clinicaltrials.gov/ct2/results?t } \\
\text { erm=FUS1- } \\
\text { nanoparticles\&Search=Search }\end{array}$ \\
\hline \multirow{3}{*}{ Liposomes } & P53 gene & SGT-53 & $\begin{array}{l}\text { Solid } \\
\text { tumours }\end{array}$ & Phase I & $\begin{array}{l}\text { SynerGene Therapeutics, Inc } \\
\text { http://clinicaltrials.gov/show/NCT0 } \\
\underline{0470613}\end{array}$ \\
\hline & \multirow{2}{*}{ Daunorubicin } & \multirow{2}{*}{ Daunoxome } & $\begin{array}{l}\text { Kaposi's } \\
\text { sarcoma }\end{array}$ & $\begin{array}{l}\text { On the } \\
\text { market }\end{array}$ & $\begin{array}{l}\text { http://www.galen.co.uk/products/da } \\
\text { unoxome } \\
\text { Galen Limited }\end{array}$ \\
\hline & & & $\begin{array}{l}\text { Myeloid } \\
\text { Leukemia }\end{array}$ & Phase II & $\begin{array}{l}\text { https://clinicaltrials.gov/ct2/show } / \mathrm{N} \\
\text { CT01238211?term=Daunoxome\&ra } \\
\text { nk=20 }\end{array}$ \\
\hline
\end{tabular}

Enhanced permeability and retention (EPR) effect is the main mechanism of drug accumulation in tumours [122]. This so-called "passive" targeting is working well for cancer diagnosis and therapy since tumours lack lymphatic drainage. This implies a simple distribution of drug or DDS by blood circulation and "targets" tumours to the same extent 
as other organs. It is suggested using a more appropriate term "drug circulation and extravasation" since about $95 \%$ of an administered drug ends up in unintended organs [123]. "Targeted" drug delivery is becoming an attractive approach in cancer therapy. Small molecule inhibitors, vitamins, hormones and antibodies can enhance drug delivery and therapeutic effects. However, "active" targeting does not necessarily mean more efficient accumulation of drug or DDS in tumours [124]. Current drugs or DDS actually cannot guide themselves to the target. "Active" targeting involves specific drug and receptor interactions that occur only after the drug or DDS is circulated in the blood. This may explain the increase in EPR effect by introducing stealth DDS with PEG coating [125]. Drug targeting can be accomplished only when DDS and receptor are in close proximity. Cell surface receptor-mediated endocytosis can be achieved through drug conjugation with such targeting molecules. Folate receptor targeting is a widely exploited concept [126] since cancer cells overexpress folate receptors [127].

Moieties marking specific cell surface proteins may also be used to target certain cell types. Fibroblast growth factor receptors (FGFR) are overexpressed in breast cancer and a wide variety of other tumour types [128]. Another popular approach is targeting cluster of differentiation (CD) proteins anchored on cell surface, for instance CD54 overexpressed in prostate cancer [129].

There is an emerging targeting approach pioneered by Russell-Jones et al. exploiting cobalamin (vitamin B12) pathway [130]. Cobalamin has a versatile uptake mechanism and is efficiently absorbed through clinically relevant ways such as oral (intestinal delivery), systemic (intravenous delivery) and topical (mucosal delivery) [131]. Vitamin B12 is involved in cellular metabolism affecting DNA synthesis and regulation in addition to fatty acid metabolism and amino acid metabolism. Vitamin B12 is an essential biomolecule for proliferating cells. However, application of cobalamin-targeting still remains widely unexplored and has a great potential for drug targeting applications [132].

\subsection{Internalization of nanocarriers}

DDS afford better internalization of therapeutic and diagnostic molecules within the body with lowest effects comparing with the conventional therapies. NPs are developed to target different biomolecules in a carry mode. Taking advantage of the tumour morphology, cell proliferation, antigen expression and leaky tumour vasculature, NPs are designed for an efficient drug delivery [4]. In fact, this uptake and distribution in the body is based on various physicochemical characteristics of NPs such as NP-based nanocarrier, size, shape and surface charge $[4,133,134]$. NP-based nanocarriers are fundamental polymeric NPs (PLGA, PLA, chitosan, gelatin, polycaprolactone and poly-alkyl-cyanoacrylates), liposomes (lipid bilayers), dendrimers (branched molecules), nanoemulsions, quantum dots (semiconductormaterials), gels, prodrugs, cyclodextrins and metal NPs (gold) [35, 101, 135-138]. According to different point of view, NPs less than 20-50 nm in hydrodynamic diameter are able to cross through blood vessels walls, by intravenous injections as well as intramuscular and subcutaneous applications [4, 134, 139, 140]. Also, spherical NPs are better internalized than rod-shaped NPs [139]. Surface functionalization with antibodies, tumour-specific antigens, short peptides, folate $\mathrm{pH}$ sensitive agents, polymers, confers to NPs better biocompatibility, solubility and stability, important properties to cross biological barriers $[4,133,141]$. Also, their modified surface can improve their non-recognition and clearance by mononuclear phagocytosis [21]. 
To develop nanosystem-based DDS it is crucial to understand their behaviour in tumour cells and tissues. Possible mechanisms of drug delivery to tumours will depend whether the nanocarrier passively or actively targets the cancer cells [107, 142]. For active targeting a moiety having selective affinity to specific cells is conjugated with the nanocarrier surface to be specifically recognized by a receptor of the cancer cells [21]. Molecules that act as penetration enhancers are capable to recognize and bind to certain surface biomolecules, allowing to minimize the anticancer drug uptake by normal cells and to increase the retention of drug into tumour cells $[4,36]$. Other targets can be specific antigens (receptors, enzymes, peptides) [107]. Several studies suggest folic acid, epidermal growth factor (EGF) and metal receptor binding ligands for the functionalization of NP surface for recognition of cancer cells and angiogenic microcapillaries growing around tumour cells [4, 143, 144]. However, if these ligands are also expressed in normal cells the nanocarriers will be nonspecific for cancer cells [7]. Accumulation of nanocarriers can also be achieved gradually at the target site via enhanced permeability and retention (EPR) effect in solid tumours.

Tumours often have leaky blood vessels with irregular shape and disorganized endothelial cells, thus, promoting the EPR effect, allowing NPs extravasation from blood flow (Figure $5)[6,21,145]$. This process increases absorption of nutrients and oxygen required for the production of fibroblast growth factor (FGF) and VEGF, which stimulate the growth of new blood and lymphatic vessels in the tumour [6, 146-148].

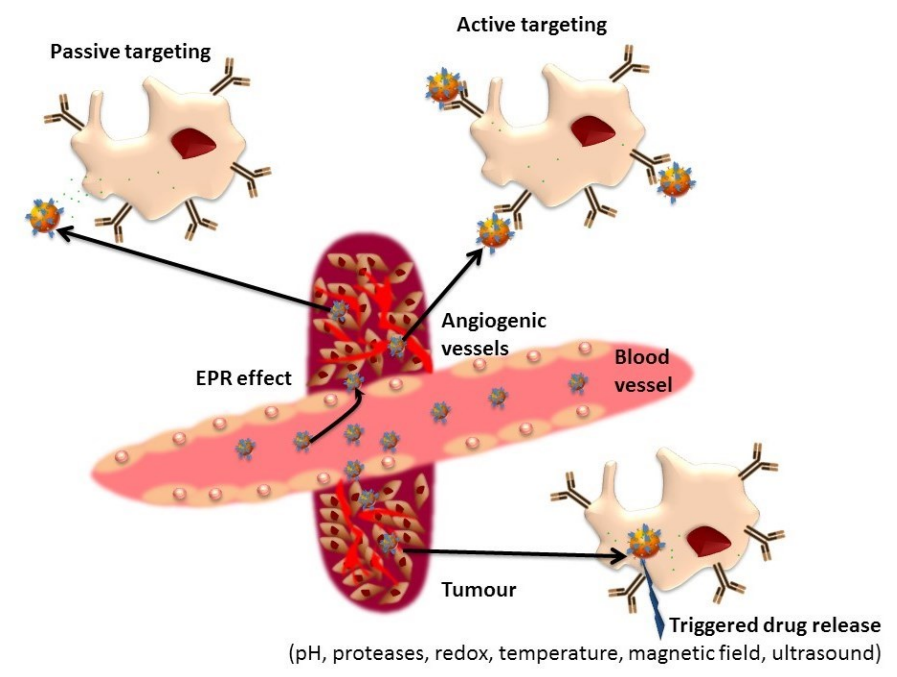

Figure 5. Illustration of active and passive targeting delivery.

Nanocarriers have the capacity to enhance drug delivery by passive targeting due to the EPR effect in conjunction with their increased circulation half-life time.

Several studies report that NPs are internalized into cancer cells through endocytosis (Figure 6) [108, 139, 149]. Usually in biological environment serum proteins adsorb on NP surface facilitating the uptake mechanism by the formation of endocytic vesicles [139]. 


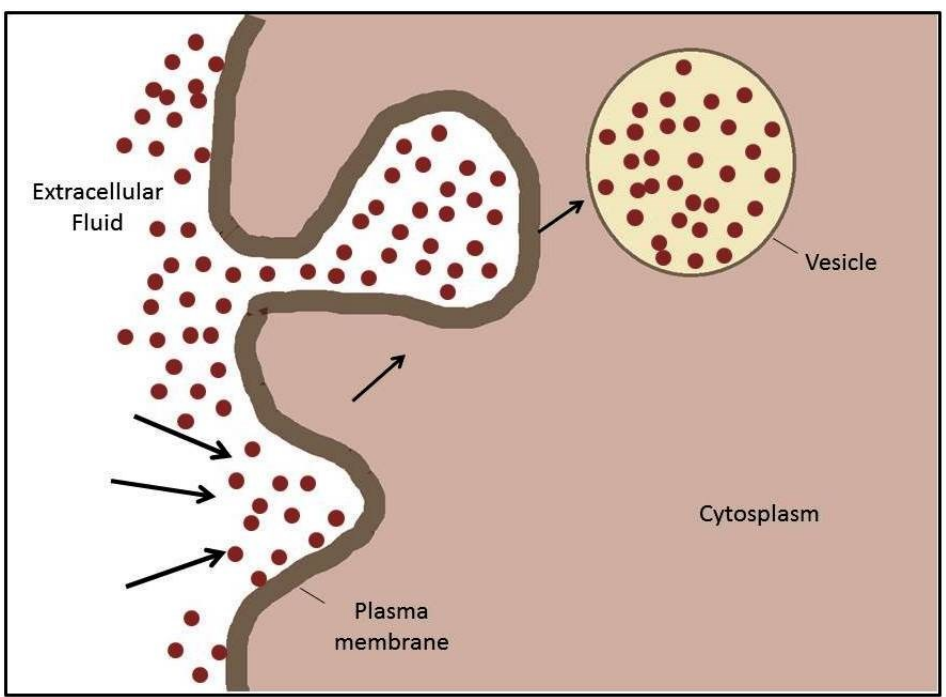

Figure 6. Endocytosis process involving invagination of plasma membrane and formation of endocytic vesicles containing the nanocarrier-drug complexes.

Kim et al. studied the influence of NP internalization on cell cycle phase [150] and showed that another relevant factor on uptake mechanism is NP surface functionalization. Techniques such as transmission electron microscopy (TEM) and laser scanning confocal microscopy (LSCM) have been useful in understanding the mechanisms of NP uptake and toxicity [149, 151-153].

Further in this review we will focus on polymeric and inorganic NPs, in particular, gold/polymeric nanoparticles for cancer therapy.

\section{Metal-based nanoparticles}

Metal NPs have been studied for drug delivery applications in chemotherapy and diagnostics. Inert metals such as gold and titanium are the ones most commonly used for controlled release of anticancer drugs [154].

Gold NPs (AuNPs) are functional inorganic NPs. Different shapes (spheres, rods, tubes, wires, ribbons, cubic, hexagonal, triangular) and sizes can be achieved in a controlled way [155-158]. Usually spherical AuNPs are used for DDS applications (Figure 7). The biphasic Brust-Schiffrin method uses tetraoctylammonium bromide as the phase transfer reagent and sodium borohydride as reducing agent allowing the preparation of AuNPs with a hydrodynamic diameter between 1 and $5 \mathrm{~nm}[159,160]$. Turkevitch et al. synthesized AuNPs with diameter ranging from 10 to $100 \mathrm{~nm}$ by the reduction of $\mathrm{HAuCl}_{4}$ with sodium citrate $[161,162]$. Colloidal AuNPs can be made for dispersion in different solvents:

Hydrophilic AuNPs for water-based solvent and hydrophobic ones in organic solvent [141]. 


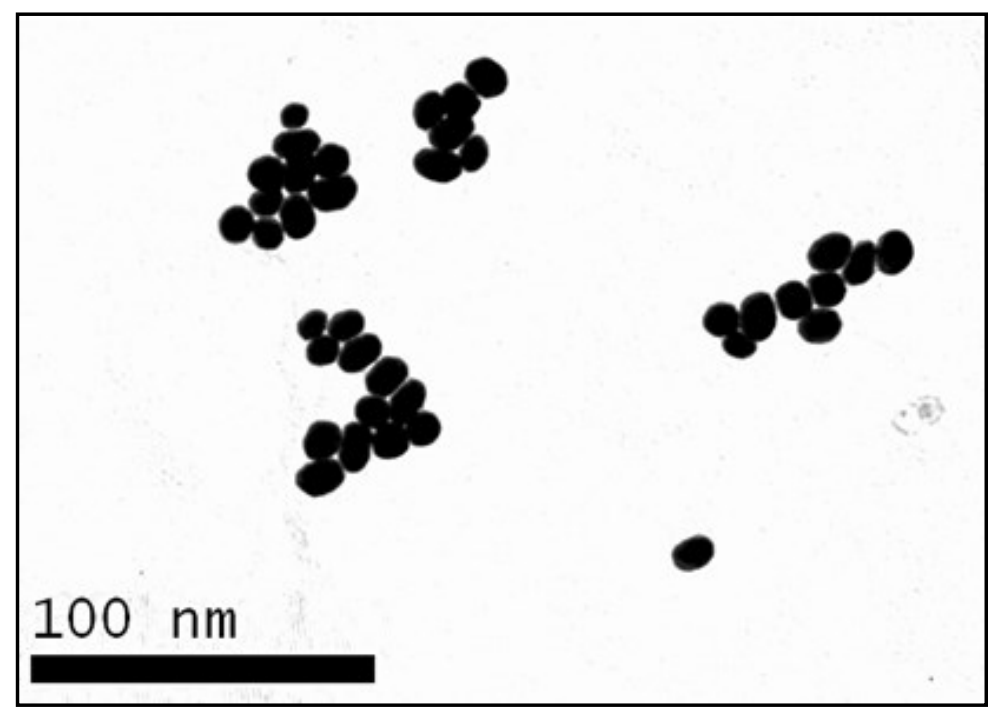

Figure 7. TEM image of AuNPs. Typically spherical AuNPs are produced with average diameter of about 5-50 nm

AuNPs have achieved great attention in research due to their inherent unique optical and chemical properties such as high electron density and strong optical absorption [141, 163]. Gold colloids present a characteristic strong surface plasmon resonance band at around 520 $\mathrm{nm}$ and absorb throughout the visible and near infrared region rendering them active for biological purposes [9, 164, 165].

AuNPs have a high tumour retention capacity due to their natural affinity to leaky tumour vasculature [166]. Some reports suggest the anti-angiogenic effects of AuNPs by inhibition of VEGF-induced angiogenesis [14, 167].

Charge, surface functionalization, stability and size of AuNPs are important factors for the cellular uptake process [168-170]. Relatively easy surface modification chemistry through thiol linkages provides large reactive surface area and great ability to carry high drug doses $[143,165,171,172]$. It is being debated which mechanism is suitable for efficient NP uptake by cells. Positively-charged NPs can be rapidly uptaken by tumour cells. However, the presence of positive charges at the NP surface also leads to immune reactions [8]. The mechanism how gold nanoparticles are internalized by cancer cells is shown in the scheme of Figure 8 and reported in our previous work ([43] supplementary information). 


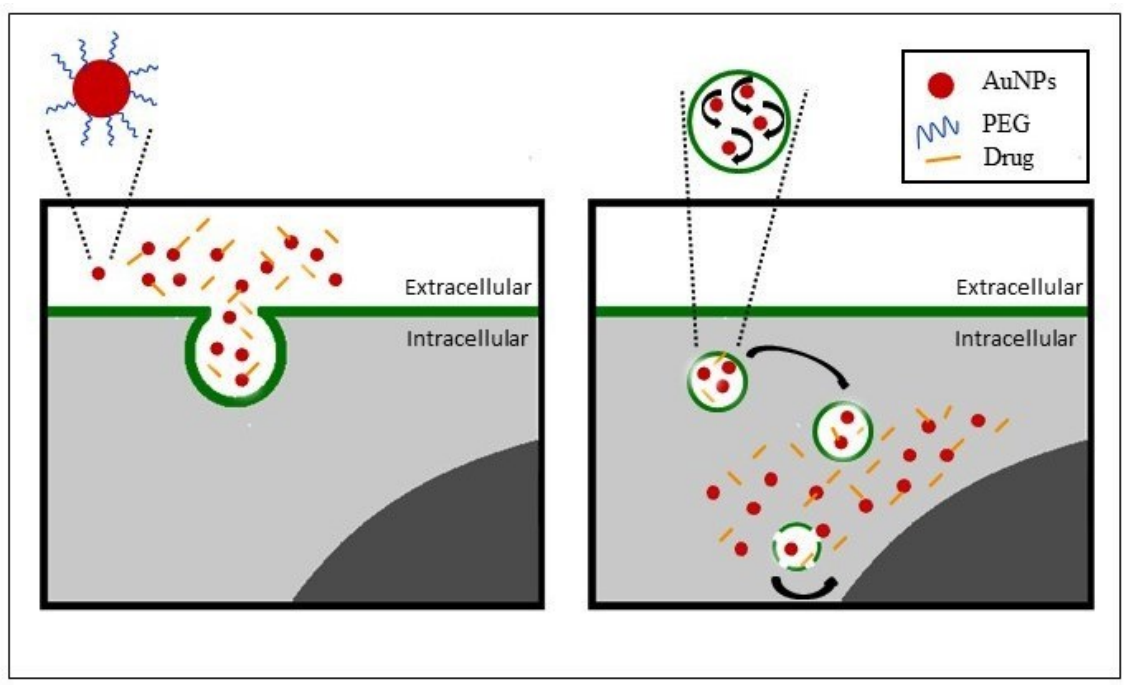

Figure 8. Uptake mechanism of gold nanoparticles.

Therefore, neutral or negative NPs are considered better systems for clinical applications $[8,173,174]$. Most efficient cell internalization is observed for NPs with size ranging between 20 and $50 \mathrm{~nm}$. Chan et al. showed that AuNPs with a diameter between 14 and 74 $\mathrm{nm}$ are able to be internalized by HeLa cells [175]. We have shown efficient distribution of $38 \mathrm{~nm}$ pegylated gold NPs (PEGAuNPs) in pancreatic cancer cells (Figure 9) [43]. Biocompatibility of AuNPs is assessed by the in vitro AuNPs toxicity studies, suggesting the impact of physico-chemical properties of AuNPs on the toxicity in the cells [176]. Nevertheless, this research reports non-toxicity of small AuNPs in cells (less than $100 \mathrm{~nm}$ in diameter) with low concentrations and administration time depending on the type of cell lines $[43,140,176]$. Chen et al. studies confirm that spherical AuNPs with $21 \mathrm{~nm}$ do not show cell toxicity in mice [140]. Coelho et al. reported that PEGAuNPs are not toxic at concentration $1.0 \mathrm{nM}$ in prostate cancer cells [43]. Additionally the study of Sadauskas suggested the inert characteristic of AuNPs and no side effects were detected [177]. In vivo studies reported the fate and excretion of AuNPs. The aim is to control the size and the shape of the NPs to minimize the potential toxicity. Also, physical and chemical characteristics of AuNPs can affect the absorption, metabolism, distribution and clearance [176]. Absorption of AuNPs is dependent on administration (intravenous, oral or intrarectal) and NPs size is crucial to minimize the systemic absorption, distribution and simultaneously to improve urinary and fecal excretion $[174,176]$. Gold is excreted in the urine and feces but the percentage of excretion is different from patient to patient [174]. Zhang et al. reported AuNPs with large size are accumulated in liver and spleen. However, they also reported that small AuNPs are cleared by renal system [178]. It was demonstrated by Zhang that glutathione-loaded AuNPs are metabolized by renal clearance while Bovine Serum Albumin-loaded AuNPs show damages in liver, kidney and mice infection [178]. 


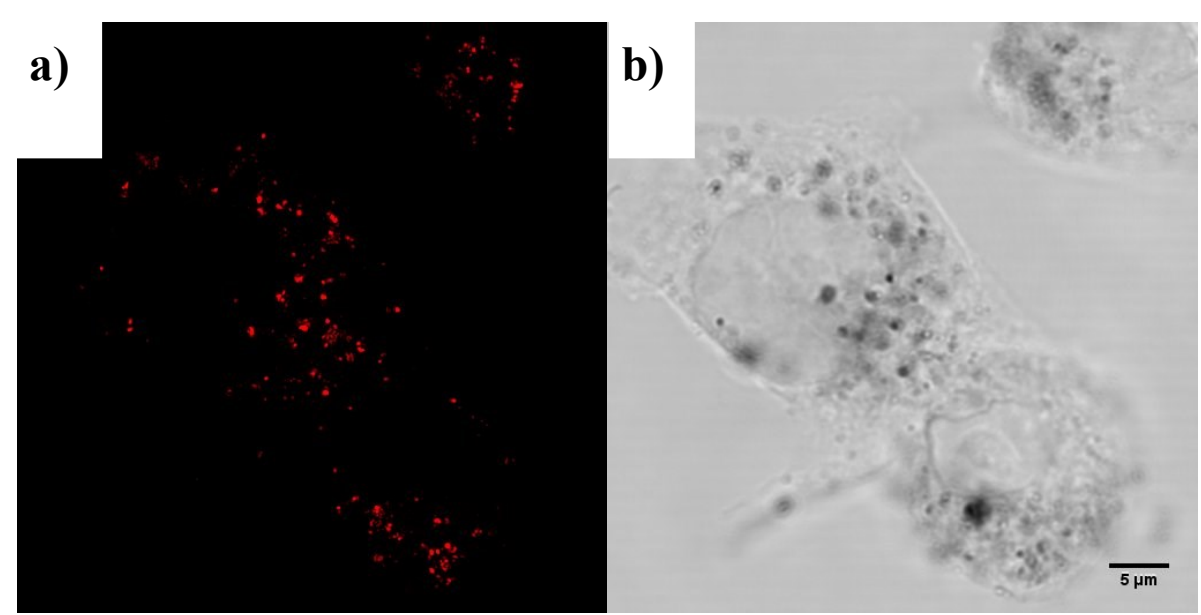

Figure 9. Cellular uptake PEGAuNPs in pancreatic cancer cells imaged by laser scanning confocal microscopy in a) reflection mode and b) transmission mode.

AuNPs are used for many biomedical applications including drug delivery vectors based on covalent reaction, drug encapsulation, electrostatic adsorption and non-covalent conjugation [11, 105, 179-182]. AuNPs can improve anticancer effects of many drugs by increasing drug delivery to cancer cells [183], which can be facilitated by passive or active targeting mechanisms [184].

Several studies showed that AuNPs interact with serum proteins. Chithrani et al. suggested that serum proteins are adsorbed on the particle surface creating a corona of protein layer, which mediate the AuNP internalization via endocytosis [175]. Also, AuNPs may be a potential vector to avoid RES clearance and enhance endothelial diffusion [179]. Mirkin et al. suggested that paclitaxel loaded oligonucleotide AuNPs may overcome the drug-efflux in MDR cancers [185]. A cytotoxicity study with doxorubicin (DOX) loaded PEGAuNPs in hepatocellular cell line HepG2R showed ability to overcome MDR compared to the free drug [186]. The study demonstrated that the Au-PEG-SS-DOX nanoconjugate system efficiently released the drug and enhanced its cytotoxicity against MDR cancer cells. This study highlights the potential of using AuNPs for overcoming MDR in cancer chemotherapy. Another example is DOX-conjugated AuNPs for treatment of breast cancer [187]. These results showed an increase in cancer cell death compared to the free DOX and an outgrown drug efflux from the cells.

Patra et al. reported gemcitabine (anticancer drug) and cetuximab (human epidermal growth factor receptor, EGFR, targeting drug) conjugated to AuNPs as an efficient nanosystem for inhibition of pancreatic tumour cell proliferation in vitro and in vivo [164]. Bhumkar et al. reported chitosan functionalized AuNPs used for transmucosal delivery of insulin [188]. These results suggested that chitosan-AuNPs improved pharmacodynamic activity of insulin. Jiang et al. suggested that coating of AuNPs with hercepticin enhances their uptake in human breast cancer SK-BR-3 cells overexpressing receptor tyrosine-protein kinase ErbB2 (also known as EGFR2 or HER2) [189]. Barchi et al. investigated AuNPs conjugated with Thomsen-Friedenreich antigen (TF-Ag). The TF-Ag-AuNPs were injected intraperitoneally in mice bearing 4T1 murine breast cancer model [190] and it was observed that the nanosystem inhibited the tumour growth [190].

Brown et al. revealed significant proliferation inhibition of lung epithelial cancer A549 cells treated with oxaliplatin adsorbed onto PEGAuNPs [191]. Coelho et al. demonstrated 
synergistic effect of bortezomib, a proteasome inhibitor, and PEGAuNPs on the inhibition of pancreatic (S2013) and prostate (Du145) cancer cell growth (Figure 10) [43]. Significant decrease in the proliferation of S2-013 and Du145 cells were observed while similar effect is not expressed in normal cells as pancreatic hTERT-HPNEs [43].

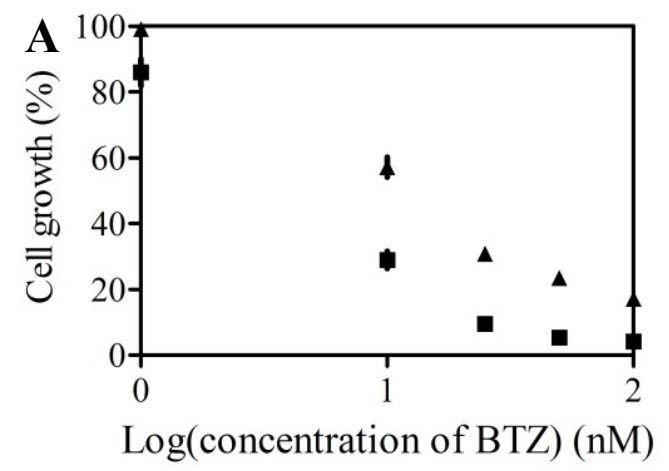

Figure 10. Effect of bortezomib (BTZ) plus PEGAuNPs $0.1 \mathrm{nM}(\mathbf{\square})$ and BTZ alone $(\boldsymbol{\Delta})$ on the growth of pancreatic cancer S2-013 cells (A) and prostate cancer Du145 cells (B) as determined by sulforhodamine B (SRB) and Methylene Blue assays, respectively.

One phase I clinical trial study showed efficient internalization of aurimune (CYT-6091), which is a PEGAuNP carrier of recombinant human tumour necrosis factor alpha (rhTNF) [192]. Aurimune acts as a Trojan horse moving sneakily through the body and entering cancer cells to destroy their defence mechanisms. Another promising application of AuNPs is the possibility to incorporate them into liposomes, micelles, dendrimers or polymeric matrices [193-198]. Kim et al. reported a combination of AuNPs and poly-(amidoamine) dendrimers that improve the quality and control of AuNP properties [199]. Nativo et al. showed controlled intracellular uptake of AuNPs by liposomes [200] Furthermore, Chithrani et al. demonstrated a thousand-fold enhancement in cellular uptake of small (1.4 $\mathrm{nm}) \mathrm{Au}$ NPs by liposomes [201]. Paasonen et al. suggested a principle of controlled drug release from liposomes by photothermal effect of AuNPs exposed to ultraviolet (UV) irradiation [202].

Due to unique optical properties of surface plasmon resonance of AuNPs drug delivery by this nanosystem can be combined with non-invasive non-ionizing therapeutic approaches such as radiofrequency ablation (RFA), photothermal therapy (PTT) or photodynamic therapy (PDT). Since AuNPs are good absorbers of ionizing radiation they can also be used for enhancement of radiotherapy (RT). Provided targeting AuNPs are employed the above mentioned combination therapies will selectivity damage specific cells [57, 160, 183, 203205].

Application of NPs with radiotherapy is an emerging field to explore the combination of drug targeting and radiation dose enhancement. Damage to deoxyribonucleic acid (DNA) caused by radiation leads to size reduction and destruction of tumours [4, 205, 206]. Therefore, if NPs act as radiopharmaceuticals or radiosensitizers such cancer treatment modality can be significantly improved [4, 207]. Metallic NPs can enhance radiation effects by scattering and/or absorbing high-energy electromagnetic waves (X-rays and gamma rays) [57]. 
Many studies report AuNPs as diagnostic and therapeutic nanomedicines. Kattumuri et al. suggested AuNP-contrast X-ray imaging [208]. Better anticancer effects were proved when NPs were combined with anticancer drugs and non-ionizing radiofrequency (RF) radiation. Glazer et al. showed in vivo increase in pancreatic cancer cell apoptosis when cetuximab, PAM4-conjugated AuNPs and RF radiation were combined [209]. El-Sayed et al. reported that the use of EGFR coated AuNPs increased the photothermal therapy effect by 20 times in human oral squamous cell carcinoma HSC3 cells [210].

Several studies have shown increase in absorption of X-rays by AuNPs internalized in cancer cells [207, 211, 212]. Hainfield et al. has reviewed application of AuNPs as radiosensitizers that increase local drug dose and at the same time enhance radiation effects [213]. Hainfeld et al. has shown that the combination of AuNPs and $250 \mathrm{kVp}$ X-ray radiation in mice-bearing EMT-6 mammary carcinoma significantly improved one-year survival rate [214]. Tumour size reduction was dependent on the amount of AuNPs injected with $50 \%$ one-year survival for $1.35 \mathrm{~g} \mathrm{Au} / \mathrm{kg}$ body weight and $86 \%$ survival for $2.7 \mathrm{~g}$ $\mathrm{Au} / \mathrm{kg}$ dose. For comparison the animal group treated only with X-rays had only $20 \%$ oneyear survival.

When combined with chemotherapeutic agents AuNPs offer a promising therapeutic strategy for advanced stage cancer patients $[11,117]$. The first clinical trial with the AuNP and rhTNF nanoconstruct (Aurimune, CYT-6091) showed no dose-limiting toxicity of rhTNF [117]. This dose-escalation study revealed that AuNPs can deliver rhTNF at the drug doses that were previously known to be toxic.

\section{Polymeric Nanoparticles}

Biocompatible, stable and biodegradable polymers have received great attention recently. These polymers can be formulated into novel nanocarriers encapsulating hydrophilic or hydrophobic anticancer drugs [4, 8, 215-217]. Natural and synthetic polymers have already been used for drug delivery in preclinical and clinical studies [218]. Some of these reports provide DDS with lipid-nanoparticles [219]. Polymeric NPs such as micelles, nanospheres, nanocapsules and polymersomes are the most frequently used in DDS. Polymeric NPs possess the following advantages for drug delivery [8, 215, 220, 221]:

- increased drug solubility

- better drug biodistribution;

- increased drug stability and circulation half-life time [9, 222, 223];

- enhanced drug accumulation in tumours due to the EPR effect [6, 224, 225];

- drug targeting to specific locations [226].

Polymeric DDS is a promising strategy to improve therapeutic index of many drugs. Several studies have reported conjugation of polymeric nanocarriers with anti-angiogenic agents to target tumour vasculature [19]. Fante et al. developed a polymeric system conjugated with dopamine, which is a neurotransmitter recently found to participate in regulation of angiogenesis. Clinical anti-angiogenic activity of dopamine has been limited due to its very short circulation time while the polymeric formulation has extended this time for up to $24 \mathrm{~h}$ [19]. Arvizo et al. suggested anti-angiogenic properties of AuNPs [227]. Inhibition of pro-angiogenic heparin-binding growth factors is caused by conformational changes induced by AuNPs leading to denaturation of the active proteins [18]. 
Polymers such as poly(lacticco-glycolic acid) (PLGA), polycaprolactone (PCL) and polysaccharides derived from algae, plants, microbial population and animals have been also in focus [221, 228, 229]. Chitosan, alginate, heparin, hyaluronic acid and dextran are examples of polysaccharides used in the nanocarriers [230, 231]. They are high molecular weight compounds classified according to their surface charges in cationic polysaccharides - chitosan - anionic polysaccharides - gum arabic, alginate, heparin, hyaluronic acid and nonionic polysaccharides - dextran $[36,215,232]$.

Chitosan $(\mathrm{Ch})$ is a natural heteropolymer of $\mathrm{N}$-acetyl-D-glucosamine and D-glucosamine linked by beta-(1-4)glycosidic bonds obtained by deacetylation of chitin [215, 233]. Ch presents low toxicity, is hydrophilic, biodegradable and soluble in acidic solutions due to protonation of the amine groups [36]. Ch plays an important role in cancer therapy and can be explored for tumour angiogenesis inhibition [234]. Ch has many advantages, including:

- ability to control release of active agents;

- avoiding the use of hazardous organic solvents while preparing particles;

- allowing for ionic crosslinking (cationic nature) with multivalent anions;

- mucoadhesive character increasing residual time at absorption site [235];

- Ch also inhibits angiogenesis process [225, 236].

Gum arabic (GA) (acacia) is a negatively charged branched polysaccharide with a high degree of biocompatibility and biodegradability [237]. The analysis of GA composition reveals the presence of a main galactan chain carrying heavily branched galactose/arabinose side chains. The carbohydrate moiety is composed of D-galactose $(40 \%$ of the residues), L-arabinose (24\%), L-rhamnose (13\%), and two types of uronic acids responsible for the polyanionic character of the gum, D-glucuronic acid (21\%) and 4-Omethyl-D-glucuronic acid (2\%) [238]. Liu et al. suggested that AuNPs can form a novel nanocomposite in the presence of GA [239]. The system can be promising for photothermal cancer treatment [239]. Effiong et al. revealed that GA-modified magnetic NPs inhibit the proliferation of $E$. coli in media [240]. Avadi et al. developed a nanoparticulate system based on ionic gelation between $\mathrm{Ch}$ and GA for oral delivery of insulin [241].

Polysaccharide-based NPs can be prepared by different mechanisms: covalent crosslinking, ionic crosslinking, polyelectrolyte complexation and self-assembly of hydrophobically modified polysaccharides (Table 4) [215, 230, 242, 243].

Table 4. Methods used for the preparation of polysaccharide-based nanoparticles.

\begin{tabular}{ll}
\hline Method & Characteristics \\
\hline $\begin{array}{l}\text { Covalent } \\
\text { crosslinking }\end{array}$ & Chemical interaction. \\
& $\begin{array}{l}\text { Polyanions/polycations with low molecular weight can } \\
\text { act as ionic crosslinkers for charged polysaccharides. } \\
\text { The most common crosslinker used is tripolyphosphate }\end{array}$ \\
$\begin{array}{l}\text { (TPP). } \\
\text { Polyelectrolyte } \\
\text { complexation }\end{array}$ & $\begin{array}{l}\text { Polymers with opposite charge surface can form } \\
\text { polysaccharide NPs by electrostatic interaction. }\end{array}$ \\
\hline
\end{tabular}




\begin{tabular}{ll}
\hline $\begin{array}{l}\text { Self-assembly of } \\
\text { hydrophobically } \\
\text { modified } \\
\text { polysaccharides }\end{array}$ & $\begin{array}{l}\text { Spontaneous formation of micelles by polymeric } \\
\text { amphiphiles through intermolecular connection between } \\
\text { hydrophobic moieties. }\end{array}$ \\
\hline
\end{tabular}

Anticancer drugs can be entrapped into NP matrix or adsorbed onto NP surface [230, 233, 244]. Loading efficacy depends on the NP formulation and drug physicochemical properties. Anticancer drugs such as doxorubicin, paclitaxel, 5-fluoroaucil can be encapsulated in polymeric NPs. Fonseca et al. reported increased inhibitory effect of paclitaxel loaded to PLGA NPs in human small cell lung cancer NCl-H69 cells when compared to the free drug [245]. Another study showed similar results in HeLa cells with higher inhibitory effect of paclitaxel-loaded PLGA NPs [246]. All studies support the use of polymeric NPs as DDS.

Nah et al. prepared paclitaxel loaded in water-soluble Ch NPs. The NPs were produced by conjugation of hydrophilic group, methoxy poly-(ethylene) glycol $p$-nitrophenyl carbonate and an hydrophobic group, cholesteryl chloroformate to the free amine groups of Ch [247]. Their results showed high NP accumulation in tumours in a murine model and, therefore, a considerable anticancer effect. Sahu et al. showed enhanced cytotoxicity of paclitaxel loaded in folic acid (FA) modified chitosan NPs in HeLa cells [248].

\section{AuNP incorporation into polysaccharide-based matrix}

In recent years, important advances have been made in polymeric NP development $[4,221$, 249]. The motivation is biodegradability of DDS synthesized by new polymers and their combinations with inorganic NPs [27]. Polymeric systems demonstrate high efficacy of encapsulation and high endocytosis by EPR effect [250]. In addition, they are able to protect systemic bioavailability, avoiding normal cells to be exposed to the drug toxicity [251-253]. The natural polymers are suitable materials to interact with the normal cells conferring to the DDS high biocompatibility [72]. The degradation compounds of biopolymers can be metabolized and rapidly cleared from the human body [27].

Several studies investigated the role of charged NPs and their interaction with negatively charged cell membrane. It has been suggested that positively charged NPs have advantages comparing to the negative ones by adsorption on the surface of negatively charged cell membrane [139]. Therefore, intracellular internalization will depend on NP charge. It also means that positively charged NPs have better plasma membrane penetration properties [139]. The major goal is thus to design inert, biocompatible and nontoxic NPs coated by biodegradable polysaccharides leading to positively charged NPs. Also, these polysaccharide based NPs are good candidates for drug delivery due to their ability to increase circulation half-life time, high drug encapsulation efficiency and controlled drug release [10]. This nanosystem has a matrix structure where anticancer drugs can be adsorbed on the surface or entrapped in the core protecting them from outside reagents [9, 218].

As already mentioned, AuNPs possess unique physico-chemical and photothermal properties turning their conjugates with polymers into very promising systems for controlled drug release with or without external radiation [254].

Though natural polymers such as $\mathrm{Ch}$ and GA are biocompatible and biodegradable they can be useful in improving stability of incorporated NPs [9]. Proper incorporation of NPs in 
polymer matrices is important for engineering of stabilized Au colloidal suspensions [195, 197]. Kannan et al. reported the therapeutic efficacy of GA-funtionalized NPs with betaemitting Au-198 isotope in prostate tumour xenografts bearing mice [166]. Tumour regression by $82 \%$ and a control in the growth of prostate tumour over was achieved after 30 days.

One possible strategy to design DDS comprising versatile AuNPs is their incorporation into a Ch-GA matrix that can be easily prepared by coacervation process [255]. The polysaccharide matrix is a result of electrostatic interactions of oppositely charged $\mathrm{Ch}$ and GA in aqueous solution [255]. The AuNPs loading process can be performed at the time of such process of coacervation [253]. The AuNPs are entrapped in the polymer matrix. Succesful internalization of such Ch-GA composites with entrapped PEGAuNPs (Ch-GAPEGAuNPs) has been achieved in pancreatic cancer S2-013 cells and immortalized human pancreatic duct epithelial hTERT-HPNE cells [253] (Figure 11).

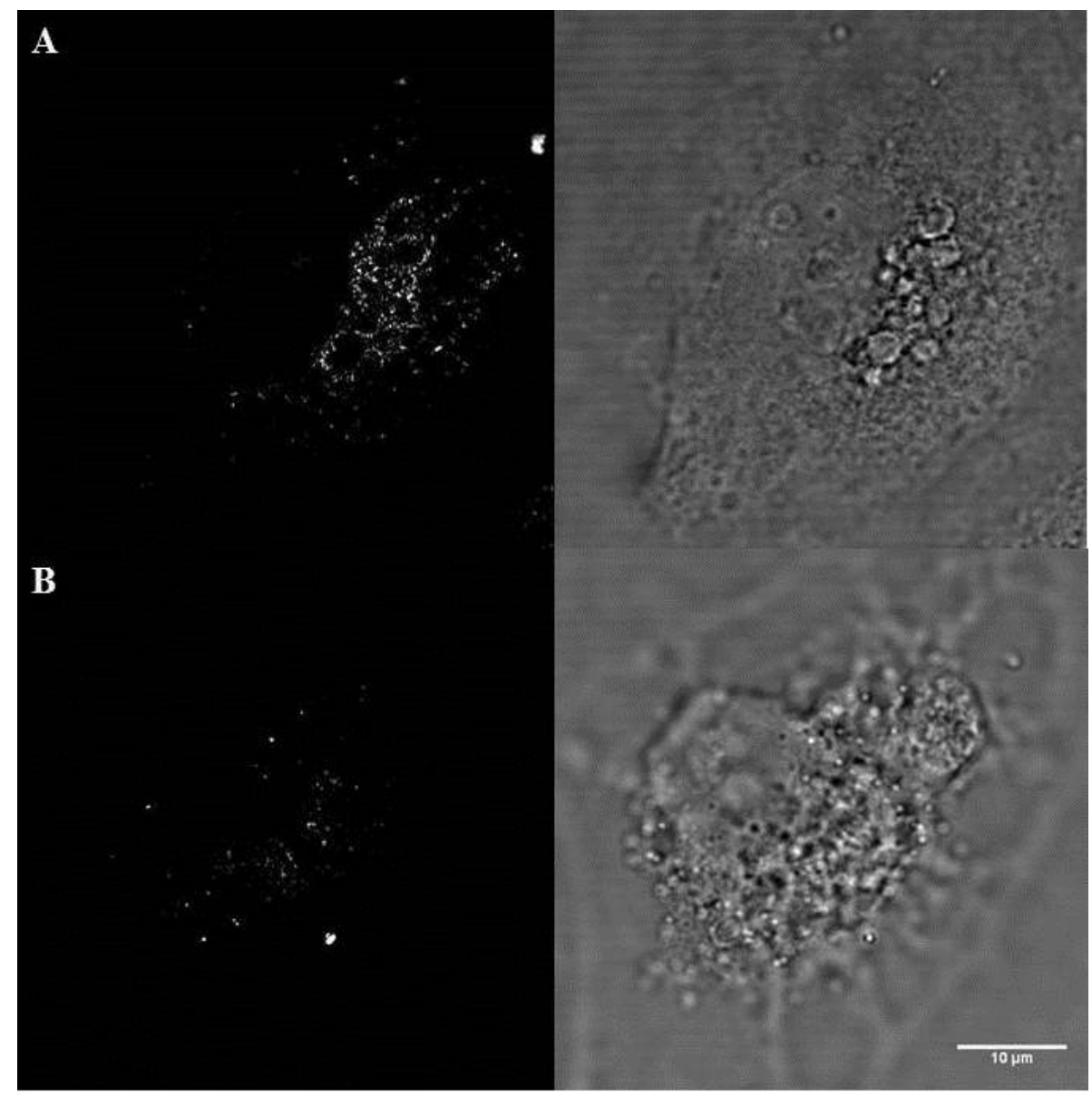

Figure 11. LSCM reflection (left) and transmission (right) images of S2-013 (A) and hTERT-HPNE (B) cells after $48 \mathrm{~h}$ incubation. The cells were incubated with Ch-GABTZ+PEGAuNPs with BTZ concentration of $100 \mathrm{nM}$. Scale bar in all images is $10 \mu \mathrm{m}$.

\section{Outline and future challenge}

DDS is a promising transport mechanism for cancer diagnosis and treatment. Different approaches are presently available for targeted drug delivery with minimal side effects. Many NP vectors have been investigated due to their specific properties, biocompatibility 
and biodegradability. However, despite the fact that some vehicles have already been successfully applied in the clinics, continuous investigation for new improvements is necessary. Search of safe nanomaterials for therapeutic applications is a challenging objective.

At present, materials such as polysaccharides and AuNPs are the most suitable candidates for a) effective combination therapies against cancer leading to enhancement of therapeutic efficacy in patients, b) lowering toxicity and undesired side-effects, and c) targeted delivery of anticancer drugs to specific sites. Conceptual understanding of pharmacokinetics, pharmacodynamics and immune responses is relevant for successful design of novel DDS for cancer diagnosis and therapy.

\section{Acknowledgements}

The financial support by TRANSCAN-FCT is acknowledged (research project TRANSCAN/0001/2012) and Portuguese Cancer League. Support from the Norwegian Cancer Society, South-Eastern Norway Regional Health Authority and Research Council of Norway is also appreciated.

\section{References}

[1] A.M.P. Omuro, S. Faivre, E. Raymond, Lessons learned in the development of targeted therapy for malignant gliomas, Molecular Cancer Therapeutics, 6 (2007) 1909-1919.

[2] S. Al-Dimassi, T. Abou-Antoun, M. El-Sibai, Cancer cell resistance mechanisms: a mini review, Clin Transl Oncol, 16 (2014) 511-516.

[3] I.S.I. J Ferlay, M Ervik, R Dikshit, S Eser, C Mathers, M Rebelo M, DM Parkin, D Forman, F Bray, GLOBOCAN 2012 v1.0, Cancer Incidence and Mortality Worldwide: IARC CancerBase, in, International Agency for Research on Cancer, Lyon, France, 2013.

[4] N.P. Praetorius, T.K. Mandal, Engineered nanoparticles in cancer therapy, Recent Pat Drug Deliv Formul, 1 (2007) 37-51.

[5] in, American Cancer Society

[6] A.K. Iyer, G. Khaled, J. Fang, H. Maeda, Exploiting the enhanced permeability and retention effect for tumor targeting, Drug Discovery Today, 11 (2006) 812-818.

[7] M. Beija, R. Salvayre, N. Lauth-de Viguerie, J.D. Marty, Colloidal systems for drug delivery: from design to therapy, Trends Biotechnol, 30 (2012) 485-496.

[8] A.Z. Wang, R. Langer, O.C. Farokhzad, Nanoparticle Delivery of Cancer Drugs, Annual Review of Medicine, 63 (2012) 185-198.

[9] S. Parveen, R. Misra, S.K. Sahoo, Nanoparticles: a boon to drug delivery, therapeutics, diagnostics and imaging, Nanomedicine, 8 (2012) 147-166.

[10] A.R. Swatantra K.S. Kushwaha, A.K. Rai, Satyawan Singh, Novel Drug Delivery System for Anticancer Drug: A Review, International Journal of PharmTech Research, 4 (2012) 542-553.

[11] F. Yang, C. Jin, S. Subedi, C.L. Lee, Q. Wang, Y. Jiang, J. Li, Y. Di, D. Fu, Emerging inorganic nanomaterials for pancreatic cancer diagnosis and treatment, Cancer Treatment Reviews, 38 (2012) 566-579.

[12] W.C. Zamboni, V. Torchilin, A.K. Patri, J. Hrkach, S. Stern, R. Lee, A. Nel, N.J. Panaro, P. Grodzinski, Best practices in cancer nanotechnology: perspective from $\mathrm{NCl}$ nanotechnology alliance, Clin Cancer Res, 18 (2012) 3229-3241.

[13] H. Maeda, J. Wu, T. Sawa, Y. Matsumura, K. Hori, Tumor vascular permeability and the EPR effect in macromolecular therapeutics: a review, J Control Release, 65 (2000) 271-284. 
[14] R. Bhattacharya, P. Mukherjee, Biological properties of "naked" metal nanoparticles, Advanced Drug Delivery Reviews, 60 (2008) 1289-1306.

[15] R.K. Jain, T. Stylianopoulos, Delivering nanomedicine to solid tumors, Nat Rev Clin Oncol, 7 (2010) 653-664.

[16] P. Carmeliet, R.K. Jain, Angiogenesis in cancer and other diseases, Nature, 407 (2000) 249-257.

[17] Z.K. Otrock, R.A.R. Mahfouz, J.A. Makarem, A.I. Shamseddine, Understanding the biology of angiogenesis: Review of the most important molecular mechanisms, Blood Cells, Molecules, and Diseases, 39 (2007) 212-220.

[18] R.R. Arvizo, S. Rana, O.R. Miranda, R. Bhattacharya, V.M. Rotello, P. Mukherjee, Mechanism of anti-angiogenic property of gold nanoparticles: role of nanoparticle size and surface charge, Nanomedicine : nanotechnology, biology, and medicine, 7 (2011) 580-587.

[19] C. Fante, A. Eldar-Boock, R. Satchi-Fainaro, H.M. Osborn, F. Greco, Synthesis and biological evaluation of a polyglutamic acid-dopamine conjugate: a new antiangiogenic agent, J Med Chem, 54 (2011) 5255-5259.

[20] I. d'Angelo, Y. Parajó, A. Horváth, G. Kéri, M.I. La Rotonda, M.J. Alonso, Improved delivery of angiogenesis inhibitors from PLGA:poloxamer blend micro- and nanoparticles, Journal of Microencapsulation, 27 (2010) 57-66.

[21] M. Beija, R. Salvayre, N. Lauth-de Viguerie, J.-D. Marty, Colloidal systems for drug delivery: from design to therapy, Trends in Biotechnology, 30 (2012) 485-496.

[22] N.A. Saunders, F. Simpson, E.W. Thompson, M.M. Hill, L. Endo-Munoz, G. Leggatt, R.F. Minchin, A. Guminski, Role of intratumoural heterogeneity in cancer drug resistance: molecular and clinical perspectives, EMBO Molecular Medicine, 4 (2012) 675-684.

[23] V. Fodale, M. Pierobon, L. Liotta, E. Petricoin, Mechanism of cell adaptation: when and how do cancer cells develop chemoresistance?, Cancer J, 17 (2011) 89-95.

[24] N. Navin, J. Kendall, J. Troge, P. Andrews, L. Rodgers, J. McIndoo, K. Cook, A. Stepansky, D. Levy, D. Esposito, L. Muthuswamy, A. Krasnitz, W.R. McCombie, J. Hicks, M. Wigler, Tumour evolution inferred by single-cell sequencing, Nature, 472 (2011) 90-94.

[25] X. Xu, Y. Hou, X. Yin, L. Bao, A. Tang, L. Song, F. Li, S. Tsang, K. Wu, H. Wu, W. He, L. Zeng, M. Xing, R. Wu, H. Jiang, X. Liu, D. Cao, G. Guo, X. Hu, Y. Gui, Z. Li, W. Xie, X. Sun, M. Shi, Z. Cai, B. Wang, M. Zhong, J. Li, Z. Lu, N. Gu, X. Zhang, L. Goodman, L. Bolund, J. Wang, H. Yang, K. Kristiansen, M. Dean, Y. Li, J. Wang, Single-cell exome sequencing reveals single-nucleotide mutation characteristics of a kidney tumor, Cell, 148 (2012) 886-895.

[26] Z. Kan, B.S. Jaiswal, J. Stinson, V. Janakiraman, D. Bhatt, H.M. Stern, P. Yue, P.M. Haverty, R. Bourgon, J. Zheng, M. Moorhead, S. Chaudhuri, L.P. Tomsho, B.A. Peters, K. Pujara, S. Cordes, D.P. Davis, V.E. Carlton, W. Yuan, L. Li, W. Wang, C. Eigenbrot, J.S. Kaminker, D.A. Eberhard, P. Waring, S.C. Schuster, Z. Modrusan, Z. Zhang, D. Stokoe, F.J. de Sauvage, M. Faham, S. Seshagiri, Diverse somatic mutation patterns and pathway alterations in human cancers, Nature, 466 (2010) 869-

873.

[27] J.F. Coelho, P.C. Ferreira, P. Alves, R. Cordeiro, A.C. Fonseca, J.R. Góis, M.H. Gil, Drug delivery systems: Advanced technologies potentially applicable in personalized treatments, The EPMA Journal, 1 (2010) 164-209.

[28] S. Kapse-Mistry, T. Govender, R. Srivastava, M. Yergeri, Nanodrug Delivery in Reversing Multidrug Resistance in Cancer Cells, Frontiers in Pharmacology, 5 (2014).

[29] J.P. Gillet, M.M. Gottesman, Mechanisms of multidrug resistance in cancer, Methods in molecular biology (Clifton, N.J.), 596 (2010) 47-76.

[30] R.A. Burrell, C. Swanton, Tumour heterogeneity and the evolution of polyclonal drug resistance, Mol Oncol, 8 (2014) 1095-1111. 
[31] G. Housman, S. Byler, S. Heerboth, K. Lapinska, M. Longacre, N. Snyder, S. Sarkar, Drug resistance in cancer: an overview, Cancers (Basel), 6 (2014) 1769-1792.

[32] S.S. Suri, H. Fenniri, B. Singh, Nanotechnology-based drug delivery systems, J Occup Med Toxicol, 2 (2007) 16.

[33] I. Brigger, C. Dubernet, P. Couvreur, Nanoparticles in cancer therapy and diagnosis, Advanced Drug Delivery Reviews, 54 (2002) 631-651.

[34] J.-P. Gillet, M. Gottesman, Mechanisms of Multidrug Resistance in Cancer, in: J. Zhou (Ed.) Multi-Drug Resistance in Cancer, Humana Press, 2010, pp. 47-76.

[35] G. Tiwari, R. Tiwari, B. Sriwastawa, L. Bhati, S. Pandey, P. Pandey, S.K. Bannerjee, Drug delivery systems: An updated review, International Journal of Pharmaceutical Investigation, 2 (2012) 2-11.

[36] J. Coelho, P. Ferreira, P. Alves, R. Cordeiro, A. Fonseca, J. Góis, M. Gil, Drug delivery systems: Advanced technologies potentially applicable in personalized treatments, EPMA Journal, 1 (2010) 164-209.

[37] L.J. Hafner A, Perina Lakoš G, Pepić I, Nanotherapeutics in the EU: an overview on current state and future directions, International Journal of Nanomedicine, 9 (2014) 1005-1023.

[38] J.A. Bauer, B.H. Morrison, R.W. Grane, B.S. Jacobs, S. Dabney, A.M. Gamero, K.A. Carnevale, D.J. Smith, J. Drazba, B. Seetharam, D.J. Lindner, Effects of interferon beta on transcobalamin IIreceptor expression and antitumor activity of nitrosylcobalamin, J Natl Cancer Inst, 94 (2002) 1010-1019.

[39] T. Seki, J. Fang, H. Maeda, Enhanced delivery of macromolecular antitumor drugs to tumors by nitroglycerin application, Cancer Sci, 100 (2009) 2426-2430.

[40] S.C. Loo, Z.Y. Tan, Y.J. Chow, S.L. Lin, Drug release from irradiated PLGA and PLLA multilayered films, J Pharm Sci, 99 (2010) 3060-3071.

[41] Z.B. Starkewolf, L. Miyachi, J. Wong, T. Guo, X-ray triggered release of doxorubicin from nanoparticle drug carriers for cancer therapy, Chem Commun (Camb), 49 (2013) 2545-2547. [42] T. Tamatani, N. Takamaru, K. Hara, M. Kinouchi, N. Kuribayashi, G. Ohe, D. Uchida, K. Fujisawa, H. Nagai, Y. Miyamoto, Bortezomib-enhanced radiosensitization through the suppression of radiation-induced nuclear factor-kappaB activity in human oral cancer cells, Int J Oncol, 42 (2013) 935-944.

[43] S.C. Coelho, S. Rocha, P. Juzenas, P. Sampaio, G.M. Almeida, F.S. Silva, M.C. Pereira, M.A.N. Coelho, Gold nanoparticle delivery-enhanced proteasome inhibitor effect in adenocarcinoma cells, Expert opinion on drug delivery, 10 (2013) 1345-1352.

[44] S.C. Coelho, S. Rocha, M.C. Pereira, P. Juzenas, M.A. Coelho, Enhancing proteasome-Inhibitor effect by functionalized gold nanoparticles, Journal of biomedical nanotechnology, 10 (2014) 717723.

[45] R. Dorati, C. Colonna, M. Serra, I. Genta, T. Modena, F. Pavanetto, P. Perugini, B. Conti, gamma-Irradiation of PEGd,IPLA and PEG-PLGA multiblock copolymers. I. Effect of irradiation doses, AAPS PharmSciTech, 9 (2008) 718-725.

[46] E.V. Shevchenko, M.I. Bodnarchuk, M.V. Kovalenko, D.V. Talapin, R.K. Smith, S. Aloni, W. Heiss, A.P. Alivisatos, Gold/Iron Oxide Core/Hollow-Shell Nanoparticles, Advanced Materials, 20 (2008) 4323-4329.

[47] L. Menichetti, A. Flori, D. Arosio, F. Conversano, D. De Marchi, S. Casciaro, L. Paduano, V. Positano, L. Manzoni, Characterization of iron oxide-gold core-shell multifunctional nanoparticles in biomedical imaging, in: Sensors, 2011 IEEE, 2011, pp. 1673-1676.

[48] C. Hoskins, Y. Min, M. Gueorguieva, C. McDougall, A. Volovick, P. Prentice, Z. Wang, A. Melzer, A. Cuschieri, L. Wang, Hybrid gold-iron oxide nanoparticles as a multifunctional platform for biomedical application, J Nanobiotechnology, 10 (2012) 27. 
[49] E.L. Bird-Lieberman, A.A. Neves, P. Lao-Sirieix, M. O'Donovan, M. Novelli, L.B. Lovat, W.S. Eng, L.K. Mahal, K.M. Brindle, R.C. Fitzgerald, Molecular imaging using fluorescent lectins permits rapid endoscopic identification of dysplasia in Barrett's esophagus, Nat Med, 18 (2012) 315-321.

[50] K. Cho, X. Wang, S. Nie, Z. Chen, D.M. Shin, Therapeutic Nanoparticles for Drug Delivery in Cancer, Clinical Cancer Research, 14 (2008) 1310-1316.

[51] C.D. Corso, A.N. Ali, R. Diaz, Radiation-induced tumor neoantigens: imaging and therapeutic implications, American Journal of Cancer Research, 1 (2011) 390-412.

[52] R.J. Passarella, D.E. Spratt, A.E. van der Ende, J.G. Phillips, H. Wu, V. Sathiyakumar, L. Zhou, D.E. Hallahan, E. Harth, R. Diaz, Targeted nanoparticles that deliver a sustained, specific release of paclitaxel to irradiated tumors, Cancer research, 70 (2010) 4550-4559.

[53] R. Arvizo, R. Bhattacharya, P. Mukherjee, Gold nanoparticles: Opportunities and Challenges in Nanomedicine, Expert opinion on drug delivery, 7 (2010) 753-763.

[54] J.M. Morachis, E.A. Mahmoud, A. Almutairi, Physical and Chemical Strategies for Therapeutic Delivery by Using Polymeric Nanoparticles, Pharmacological Reviews, 64 (2012) 505-519.

[55] M. Arruebo, R. Fernández-Pacheco, M.R. Ibarra, J. Santamaría, Magnetic nanoparticles for drug delivery, Nano Today, 2 (2007) 22-32.

[56] E. Persson, A.-S. Gustafsson, A. Carlsson, R. Nilsson, L. Knutson, P. Forsell, G. Hanisch, H. Lennernäs, B. Abrahamsson, The Effects of Food on the Dissolution of Poorly Soluble Drugs in Human and in Model Small Intestinal Fluids, Pharmaceutical Research, 22 (2005) 2141-2151. [57] P. Juzenas, W. Chen, Y.-P. Sun, M.A.N. Coelho, R. Generalov, N. Generalova, I.L. Christensen, Quantum dots and nanoparticles for photodynamic and radiation therapies of cancer, Advanced Drug Delivery Reviews, 60 (2008) 1600-1614.

[58] M.A. Lysik, S. Wu-Pong, Innovations in oligonucleotide drug delivery, J Pharm Sci, 92 (2003) 1559-1573.

[59] T. Cedervall, I. Lynch, S. Lindman, T. Berggård, E. Thulin, H. Nilsson, K.A. Dawson, S. Linse, Understanding the nanoparticle-protein corona using methods to quantify exchange rates and affinities of proteins for nanoparticles, Proceedings of the National Academy of Sciences, 104 (2007) 2050-2055.

[60] W.H. De Jong, P.J. Borm, Drug delivery and nanoparticles:applications and hazards, Int J Nanomedicine, 3 (2008) 133-149.

[61] X. Cai, J. Hu, J. Xiao, Y. Cheng, Dendrimer and cancer: a patent review (2006-present), Expert opinion on therapeutic patents, 23 (2013) 515-529.

[62] S.P. Kambhampati, R.M. Kannan, Dendrimer nanoparticles for ocular drug delivery, Journal of ocular pharmacology and therapeutics : the official journal of the Association for Ocular Pharmacology and Therapeutics, 29 (2013) 151-165.

[63] S. Mignani, S. El Kazzouli, M. Bousmina, J.P. Majoral, Expand classical drug administration ways by emerging routes using dendrimer drug delivery systems: a concise overview, Adv Drug Deliv Rev, 65 (2013) 1316-1330.

[64] K. Madaan, S. Kumar, N. Poonia, V. Lather, D. Pandita, Dendrimers in drug delivery and targeting: Drug-dendrimer interactions and toxicity issues, Journal of pharmacy \& bioallied sciences, 6 (2014) 139-150.

[65] L. Xu, H. Zhang, Y. Wu, Dendrimer Advances for the Central Nervous System Delivery of Therapeutics, ACS Chemical Neuroscience, 5 (2013) 2-13.

[66] A. Dellinger, Z. Zhou, J. Connor, A.B. Madhankumar, S. Pamujula, C.M. Sayes, C.L. Kepley, Application of fullerenes in nanomedicine: an update, Nanomedicine (Lond), 8 (2013) 1191-1208. [67] E.C. Dreaden, L.A. Austin, M.A. Mackey, M.A. El-Sayed, Size matters: gold nanoparticles in targeted cancer drug delivery, Therapeutic delivery, 3 (2012) 457-478. 
[68] J. Gautier, E. Allard-Vannier, E. Munnier, M. Souce, I. Chourpa, Recent advances in theranostic nanocarriers of doxorubicin based on iron oxide and gold nanoparticles, Journal of controlled release : official journal of the Controlled Release Society, 169 (2013) 48-61.

[69] M.S. Khan, G.D. Vishakante, H. Siddaramaiah, Gold nanoparticles: a paradigm shift in biomedical applications, Advances in colloid and interface science, 199-200 (2013) 44-58.

[70] A. Kumar, X. Zhang, X.J. Liang, Gold nanoparticles: emerging paradigm for targeted drug delivery system, Biotechnology advances, 31 (2013) 593-606.

[71] M. Shah, V.D. Badwaik, R. Dakshinamurthy, Biological applications of gold nanoparticles, J Nanosci Nanotechnol, 14 (2014) 344-362.

[72] D. Kumar, N. Saini, N. Jain, R. Sareen, V. Pandit, Gold nanoparticles: an era in bionanotechnology, Expert opinion on drug delivery, 10 (2013) 397-409.

[73] G. Luo, J. Long, B. Zhang, C. Liu, S. Ji, J. Xu, X. Yu, Q. Ni, Quantum dots in cancer therapy, Expert opinion on drug delivery, 9 (2012) 47-58.

[74] A. Acharya, Luminescent magnetic quantum dots for in vitro/in vivo imaging and applications in therapeutics, J Nanosci Nanotechnol, 13 (2013) 3753-3768.

[75] M. Geszke-Moritz, M. Moritz, Quantum dots as versatile probes in medical sciences: synthesis, modification and properties, Materials science \& engineering. C, Materials for biological applications, 33 (2013) 1008-1021.

[76] L. Loomba, T. Scarabelli, Metallic nanoparticles and their medicinal potential. Part II: aluminosilicates, nanobiomagnets, quantum dots and cochleates, Therapeutic delivery, 4 (2013) 1179-1196.

[77] S. Chinnathambi, S. Chen, S. Ganesan, N. Hanagata, Silicon Quantum Dots for Biological Applications, Advanced Healthcare Materials, 3 (2014) 10-29.

[78] C.E. Probst, P. Zrazhevskiy, V. Bagalkot, X. Gao, Quantum dots as a platform for nanoparticle drug delivery vehicle design, Adv Drug Deliv Rev, 65 (2013) 703-718.

[79] M. Adeli, R. Soleyman, Z. Beiranvand, F. Madani, Carbon nanotubes in cancer therapy: a more precise look at the role of carbon nanotube-polymer interactions, Chemical Society reviews, 42 (2013) 5231-5256.

[80] H. He, L.A. Pham-Huy, P. Dramou, D. Xiao, P. Zuo, C. Pham-Huy, Carbon Nanotubes: Applications in Pharmacy and Medicine, BioMed Research International, 2013 (2013) 12. [81] E. Luo, G. Song, Y. Li, P. Shi, J. Hu, Y. Lin, The toxicity and pharmacokinetics of carbon nanotubes as an effective drug carrier, Current drug metabolism, 14 (2013) 879-890.

[82] B.S. Wong, S.L. Yoong, A. Jagusiak, T. Panczyk, H.K. Ho, W.H. Ang, G. Pastorin, Carbon nanotubes for delivery of small molecule drugs, Adv Drug Deliv Rev, 65 (2013) 1964-2015. [83] V. Rastogi, P. Yadav, S.S. Bhattacharya, A.K. Mishra, N. Verma, A. Verma, J.K. Pandit, Carbon Nanotubes: An Emerging Drug Carrier for Targeting Cancer Cells, Journal of Drug Delivery, 2014 (2014) 23.

[84] G. Cirillo, S. Hampel, U.G. Spizzirri, O.I. Parisi, N. Picci, F. lemma, Carbon Nanotubes Hybrid Hydrogels in Drug Delivery: A Perspective Review, BioMed Research International, 2014 (2014) 17. [85] F. Tang, L. Li, D. Chen, Mesoporous Silica Nanoparticles: Synthesis, Biocompatibility and Drug Delivery, Advanced Materials, 24 (2012) 1504-1534.

[86] Z. Li, J.C. Barnes, A. Bosoy, J.F. Stoddart, J.I. Zink, Mesoporous silica nanoparticles in biomedical applications, Chemical Society reviews, 41 (2012) 2590-2605.

[87] Y. Chen, H. Chen, J. Shi, In vivo bio-safety evaluations and diagnostic/therapeutic applications of chemically designed mesoporous silica nanoparticles, Advanced materials (Deerfield Beach, Fla.), 25 (2013) 3144-3176.

[88] V. Mamaeva, C. Sahlgren, M. Linden, Mesoporous silica nanoparticles in medicine--recent advances, Adv Drug Deliv Rev, 65 (2013) 689-702. 
[89] W.X. Mai, H. Meng, Mesoporous silica nanoparticles: A multifunctional nano therapeutic system, Integrative biology : quantitative biosciences from nano to macro, 5 (2013) 19-28.

[90] Y. Wang, Q. Zhao, N. Han, L. Bai, J. Li, J. Liu, E. Che, L. Hu, Q. Zhang, T. Jiang, S. Wang, Mesoporous silica nanoparticles in drug delivery and biomedical applications, Nanomedicine: Nanotechnology, Biology and Medicine, 11 313-327.

[91] K.N. Yang, C.Q. Zhang, W. Wang, P.C. Wang, J.P. Zhou, X.J. Liang, pH-responsive mesoporous silica nanoparticles employed in controlled drug delivery systems for cancer treatment, Cancer biology \& medicine, 11 (2014) 34-43.

[92] Y.L. Colson, M.W. Grinstaff, Biologically Responsive Polymeric Nanoparticles for Drug Delivery, Advanced Materials, 24 (2012) 3878-3886.

[93] X.Q. Wang, Q. Zhang, pH-sensitive polymeric nanoparticles to improve oral bioavailability of peptide/protein drugs and poorly water-soluble drugs, Eur J Pharm Biopharm, 82 (2012) 219-229. [94] R. Cheng, F. Meng, C. Deng, H.A. Klok, Z. Zhong, Dual and multi-stimuli responsive polymeric nanoparticles for programmed site-specific drug delivery, Biomaterials, 34 (2013) 3647-3657. [95] B.E. Grottkau, X. Cai, J. Wang, X. Yang, Y. Lin, Polymeric nanoparticles for a drug delivery system, Current drug metabolism, 14 (2013) 840-846.

[96] A. Kiriyama, K. Iga, N. Shibata, Availability of polymeric nanoparticles for specific enhanced and targeted drug delivery, Therapeutic delivery, 4 (2013) 1261-1278.

[97] G. Tosi, B. Bortot, B. Ruozi, D. Dolcetta, M.A. Vandelli, F. Forni, G.M. Severini, Potential use of polymeric nanoparticles for drug delivery across the blood-brain barrier, Current medicinal chemistry, 20 (2013) 2212-2225.

[98] M.L. Pinzon-Daza, I. Campia, J. Kopecka, R. Garzon, D. Ghigo, C. Riganti, Nanoparticle- and liposome-carried drugs: new strategies for active targeting and drug delivery across blood-brain barrier, Current drug metabolism, 14 (2013) 625-640.

[99] J.C. Kraft, J.P. Freeling, Z. Wang, R.J.Y. Ho, Emerging Research and Clinical Development Trends of Liposome and Lipid Nanoparticle Drug Delivery Systems, Journal of Pharmaceutical Sciences, 103 (2014) 29-52.

[100] R. van der Meel, M.H. Fens, P. Vader, W.W. van Solinge, O. Eniola-Adefeso, R.M. Schiffelers, Extracellular vesicles as drug delivery systems: lessons from the liposome field, Journal of controlled release : official journal of the Controlled Release Society, 195 (2014) 72-85.

[101] W.H. De Jong, P.J.A. Borm, Drug delivery and nanoparticles: Applications and hazards, International Journal of Nanomedicine, 3 (2008) 133-149.

[102] Nanomedicine in Drug Delivery, CRC Press, 2013.

[103] Drug Delivery Systems, Springer Science \& Business Media, 2008.

[104] M. Singh, A. Chakrapani, D. O'Hagan, Nanoparticles and microparticles as vaccine-delivery systems, Expert Rev Vaccines, 6 (2007) 797-808.

[105] G.F. Paciotti, L. Myer, D. Weinreich, D. Goia, N. Pavel, R.E. McLaughlin, L. Tamarkin, Colloidal gold: a novel nanoparticle vector for tumor directed drug delivery, Drug Deliv, 11 (2004) 169-183. [106] G.F. Paciotti, D.G.I. Kingston, L. Tamarkin, Colloidal gold nanoparticles: a novel nanoparticle platform for developing multifunctional tumor-targeted drug delivery vectors, Drug Development Research, 67 (2006) 47-54.

[107] S. Patel, A.A. Bhirde, J.F. Rusling, X. Chen, J.S. Gutkind, V. Patel, Nano Delivers Big: Designing Molecular Missiles for Cancer Therapeutics, Pharmaceutics, 3 (2011) 34-52.

[108] T. dos Santos, J. Varela, I. Lynch, A. Salvati, K.A. Dawson, Effects of transport inhibitors on the cellular uptake of carboxylated polystyrene nanoparticles in different cell lines, PLoS ONE, 6 (2011) 19.

[109] S. Li, K.R. Schmitz, P.D. Jeffrey, J.J.W. Wiltzius, P. Kussie, K.M. Ferguson, Structural basis for inhibition of the epidermal growth factor receptor by cetuximab, Cancer cell, 7 (2005) 301-311. 
[110] L. Barraud, P. Merle, E. Soma, L. Lefrançois, S. Guerret, M. Chevallier, C. Dubernet, P. Couvreur, C. Trépo, L. Vitvitski, Increase of doxorubicin sensitivity by doxorubicin-loading into nanoparticles for hepatocellular carcinoma cells in vitro and in vivo, Journal of Hepatology, 42 (2005) 736-743.

[111] A.T. Perez, G.H. Domenech, C. Frankel, C.L. Vogel, Pegylated liposomal doxorubicin (Doxil) for metastatic breast cancer: the Cancer Research Network, Inc., experience, Cancer Invest, 2 (2002) 22-29.

[112] F.-Y. Cheng, C.-H. Su, P.-C. Wu, C.-S. Yeh, Multifunctional polymeric nanoparticles for combined chemotherapeutic and near-infrared photothermal cancer therapy in vitro and in vivo, Chemical Communications, 46 (2010) 3167-3169.

[113] J.M. Koziara, P.R. Lockman, D.D. Allen, R.J. Mumper, Paclitaxel nanoparticles for the potential treatment of brain tumors, Journal of Controlled Release, 99 (2004) 259-269.

[114] S. Parveen, M. Mitra, S. Krishnakumar, S.K. Sahoo, Enhanced antiproliferative activity of carboplatin-loaded chitosan-alginate nanoparticles in a retinoblastoma cell line, Acta Biomater, 6 (2010) 3120-3131.

[115] M.E. Werner, N.D. Cummings, M. Sethi, E.C. Wang, R. Sukumar, D.T. Moore, A.Z. Wang, Preclinical evaluation of Genexol-PM, a nanoparticle formulation of paclitaxel, as a novel radiosensitizer for the treatment of non-small cell lung cancer, Int J Radiat Oncol Biol Phys, 86 (2013) 463-468.

[116] J.M. Koziara, P.R. Lockman, D.D. Allen, R.J. Mumper, Paclitaxel nanoparticles for the potential treatment of brain tumors, J Control Release, 99 (2004) 259-269.

[117] S.K. Libutti, G.F. Paciotti, A.A. Byrnes, H.R. Alexander, Jr., W.E. Gannon, M. Walker, G.D. Seidel, N. Yuldasheva, L. Tamarkin, Phase I and pharmacokinetic studies of CYT-6091, a novel PEGylated colloidal gold-rhTNF nanomedicine, Clin Cancer Res, 16 (2010) 6139-6149.

[118] D.P. Kelsen, D. Martin, J. O'Neil, G. Schwartz, L. Saltz, M.T. Sung, R. von Borstel, J. Bertino, Phase I trial of PN401, an oral prodrug of uridine, to prevent toxicity from fluorouracil in patients with advanced cancer, J Clin Oncol, 15 (1997) 1511-1517.

[119] F. Liu, J.Y. Park, Y. Zhang, C. Conwell, Y. Liu, S.R. Bathula, L. Huang, Targeted cancer therapy with novel high drug-loading nanocrystals, J Pharm Sci, 99 (2010) 3542-3551.

[120] R. Xing, X. Wang, C. Zhang, J. Wang, Y. Zhang, Y. Song, Z. Guo, Superparamagnetic magnetite nanocrystal clusters as potential magnetic carriers for the delivery of platinum anticancer drugs, Journal of Materials Chemistry, 21 (2011) 11142-11149.

[121] C.P. Hollis, H.L. Weiss, M. Leggas, B.M. Evers, R.A. Gemeinhart, T. Li, Biodistribution and bioimaging studies of hybrid paclitaxel nanocrystals: lessons learned of the EPR effect and imageguided drug delivery, J Control Release, 172 (2013) 12-21.

[122] V. Torchilin, Tumor delivery of macromolecular drugs based on the EPR effect, Adv Drug Deliv Rev, 63 (2011) 131-135.

[123] Y.H. Bae, K. Park, Targeted drug delivery to tumors: myths, reality and possibility, Journal of controlled release : official journal of the Controlled Release Society, 153 (2011) 198-205.

[124] A.S. Mikhail, C. Allen, Block copolymer micelles for delivery of cancer therapy: transport at the whole body, tissue and cellular levels, Journal of controlled release : official journal of the Controlled Release Society, 138 (2009) 214-223.

[125] K.F. Pirollo, E.H. Chang, Does a targeting ligand influence nanoparticle tumor localization or uptake?, Trends Biotechnol, 26 (2008) 552-558.

[126] E.Q. Song, Z.L. Zhang, Q.Y. Luo, W. Lu, Y.B. Shi, D.W. Pang, Tumor cell targeting using folateconjugated fluorescent quantum dots and receptor-mediated endocytosis, Clin Chem, 55 (2009) 955-963. 
[127] J. Sudimack, R.J. Lee, Targeted drug delivery via the folate receptor, Adv Drug Deliv Rev, 41 (2000) 147-162.

[128] A. Szlachcic, K. Pala, M. Zakrzewska, P. Jakimowicz, A. Wiedlocha, J. Otlewski, FGF1-gold nanoparticle conjugates targeting FGFR efficiently decrease cell viability upon NIR irradiation, Int J Nanomedicine, 7 (2012) 5915-5927.

[129] A.Y. Liu, Differential expression of cell surface molecules in prostate cancer cells, Cancer Res, 60 (2000) 3429-3434.

[130] G.J. Russell-Jones, Use of vitamin B12 conjugates to deliver protein drugs by the oral route, Crit Rev Ther Drug Carrier Syst, 15 (1998) 557-586.

[131] A.K. Petrus, T.J. Fairchild, R.P. Doyle, Traveling the vitamin B12 pathway: oral delivery of protein and peptide drugs, Angew Chem Int Ed Engl, 48 (2009) 1022-1028.

[132] G. Russell-Jones, K. McTavish, J. McEwan, Preliminary studies on the selective accumulation of vitamin-targeted polymers within tumors, J Drug Target, 19 (2011) 133-139.

[133] J. Voigt, J. Christensen, V.P. Shastri, Differential uptake of nanoparticles by endothelial cells through polyelectrolytes with affinity for caveolae, Proceedings of the National Academy of Sciences, 111 (2014) 2942-2947.

[134] A.Z. Wang, R. Langer, O.C. Farokhzad, Nanoparticle delivery of cancer drugs, Annual review of medicine, 63 (2012) 185-198.

[135] Y. Li, X. Zhang, D. Cao, Nanoparticle hardness controls the internalization pathway for drug delivery, Nanoscale, 7 (2015) 2758-2769.

[136] S.C. McBain, H.H.P. Yiu, J. Dobson, Magnetic nanoparticles for gene and drug delivery, International Journal of Nanomedicine, 3 (2008) 169-180.

[137] T.M. Allen, P.R. Cullis, Liposomal drug delivery systems: from concept to clinical applications, Adv Drug Deliv Rev, 65 (2013) 36-48.

[138] A. Kumari, S.K. Yadav, S.C. Yadav, Biodegradable polymeric nanoparticles based drug delivery systems, Colloids and Surfaces B: Biointerfaces, 75 (2010) 1-18.

[139] A. Verma, F. Stellacci, Effect of Surface Properties on Nanoparticle-Cell Interactions, Small, 6 (2010) 12-21.

[140] H. Chen, A. Dorrigan, S. Saad, D.J. Hare, M.B. Cortie, S.M. Valenzuela, In vivo study of spherical gold nanoparticles: inflammatory effects and distribution in mice, PloS one, 8 (2013) e58208.

[141] R.A. Sperling, W.J. Parak, Surface modification, functionalization and bioconjugation of colloidal inorganic nanoparticles, 2010.

[142] Y. Malam, M. Loizidou, A.M. Seifalian, Liposomes and nanoparticles: nanosized vehicles for drug delivery in cancer, Trends in Pharmacological Sciences, 30 (2009) 592-599.

[143] R. Bhattacharya, C.R. Patra, A. Earl, S. Wang, A. Katarya, L. Lu, J.N. Kizhakkedathu, M.J. Yaszemski, P.R. Greipp, D. Mukhopadhyay, P. Mukherjee, Attaching folic acid on gold nanoparticles using noncovalent interaction via different polyethylene glycol backbones and targeting of cancer cells, Nanomedicine : nanotechnology, biology, and medicine, 3 (2007) 224-238.

[144] M.P. Melancon, W. Lu, Z. Yang, R. Zhang, Z. Cheng, A.M. Elliot, J. Stafford, T. Olson, J.Z. Zhang, C. Li, In vitro and in vivo targeting of hollow gold nanoshells directed at epidermal growth factor receptor for photothermal ablation therapy, Molecular Cancer Therapeutics, 7 (2008) 17301739.

[145] S.Y. Yoo, S.M. Kwon, Angiogenesis and Its Therapeutic Opportunities, Mediators of Inflammation, 2013 (2013) 11.

[146] B.R. Zetter, Angiogenesis and tumor metastasis, Annu Rev Med, 49 (1998) 407-424.

[147] N. Nishida, H. Yano, T. Nishida, T. Kamura, M. Kojiro, Angiogenesis in cancer, Vasc Health Risk Manag, 2 (2006) 213-219. 
[148] D. Bartczak, O.L. Muskens, T. Sanchez-Elsner, A.G. Kanaras, T.M. Millar, Manipulation of in Vitro Angiogenesis Using Peptide-Coated Gold Nanoparticles, ACS Nano, 7 (2013) 5628-5636. [149] H. Gao, Z. Yang, S. Zhang, S. Cao, S. Shen, Z. Pang, X. Jiang, Ligand modified nanoparticles increases cell uptake, alters endocytosis and elevates glioma distribution and internalization, Sci Rep, 3 (2013).

[150] J.A. Kim, C. Åberg, A. Salvati, K.A. Dawson, Role of cell cycle on the cellular uptake and dilution of nanoparticles in a cell population, Nat Nanotechnol, 7 (2012) 62-68.

[151] M. Geiser, O. Quaile, A. Wenk, C. Wigge, S. Eigeldinger-Berthou, S. Hirn, M. Schäffler, C. Schleh, W. Möller, M. Mall, W. Kreyling, Cellular uptake and localization of inhaled gold nanoparticles in lungs of mice with chronic obstructive pulmonary disease, Part Fibre Toxicol, 10 (2013) 1-10.

[152] S.R. Abulateefeh, S.G. Spain, K.J. Thurecht, J.W. Aylott, W.C. Chan, M.C. Garnett, C. Alexander, Enhanced uptake of nanoparticle drug carriers via a thermoresponsive shell enhances cytotoxicity in a cancer cell line, Biomaterials Science, 1 (2013) 434-442.

[153] J. Singh, D. Michel, J. Chitanda, R. Verrall, I. Badea, Evaluation of cellular uptake and intracellular trafficking as determining factors of gene expression for amino acid-substituted gemini surfactant-based DNA nanoparticles, Journal of nanobiotechnology, 10 (2012) 7.

[154] C. Minelli, S.B. Lowe, M.M. Stevens, Engineering Nanocomposite Materials for Cancer Therapy, Small, 6 (2010) 2336-2357.

[155] M.-C. Daniel, D. Astruc, Gold Nanoparticles: Assembly, Supramolecular Chemistry, Quantum-Size-Related Properties, and Applications toward Biology, Catalysis, and Nanotechnology, Chemical Reviews, 104 (2003) 293-346.

[156] B. Duncan, C. Kim, V.M. Rotello, Gold nanoparticle platforms as drug and biomacromolecule delivery systems, Journal of Controlled Release, 148 (2010) 122-127.

[157] A.R. Tao, S. Habas, P. Yang, Shape Control of Colloidal Metal Nanocrystals, Small, 4 (2008) 310-325.

[158] Y. Xia, W. Li, C.M. Cobley, J. Chen, X. Xia, Q. Zhang, M. Yang, E.C. Cho, P.K. Brown, Gold nanocages: from synthesis to theranostic applications, Acc Chem Res, 44 (2011) 914-924.

[159] P.J.G. Goulet, R.B. Lennox, New Insights into Brust-Schiffrin Metal Nanoparticle Synthesis, Journal of the American Chemical Society, 132 (2010) 9582-9584.

[160] R. Arvizo, R. Bhattacharya, P. Mukherjee, Gold nanoparticles: opportunities and challenges in nanomedicine, Expert Opin Drug Deliv, 7 (2010) 753-763.

[161] G. Frens, Controlled nucleation for regulation of particle-size in monodisperse gold suspensions, Nature-Physical Science, 241 (1973).

[162] J. Turkevich, P.C. Stevenson, J. Hillier, A study of the nucleation and growth processes in the synthesis of colloidal gold, Discussions of the Faraday Society, 11 (1951) 55-75.

[163] Y. Xia, W. Li, C.M. Cobley, J. Chen, X. Xia, Q. Zhang, M. Yang, E.C. Cho, P.K. Brown, Gold Nanocages: From Synthesis to Theranostic Applications, Accounts of Chemical Research, 44 (2011) 914-924.

[164] C.R. Patra, R. Bhattacharya, E. Wang, A. Katarya, J.S. Lau, S. Dutta, M. Muders, S. Wang, S.A. Buhrow, S.L. Safgren, M.J. Yaszemski, J.M. Reid, M.M. Ames, P. Mukherjee, D. Mukhopadhyay, Targeted Delivery of Gemcitabine to Pancreatic Adenocarcinoma Using Cetuximab as a Targeting Agent, Cancer Research, 68 (2008) 1970-1978.

[165] D.A. Giljohann, D.S. Seferos, W.L. Daniel, M.D. Massich, P.C. Patel, C.A. Mirkin, Gold nanoparticles for biology and medicine, Angew Chem Int Ed Engl, 49 (2010) 3280-3294.

[166] N. Chanda, P. Kan, L.D. Watkinson, R. Shukla, A. Zambre, T.L. Carmack, H. Engelbrecht, J.R. Lever, K. Katti, G.M. Fent, S.W. Casteel, C.J. Smith, W.H. Miller, S. Jurisson, E. Boote, J.D. Robertson, C. Cutler, M. Dobrovolskaia, R. Kannan, K.V. Katti, Radioactive gold nanoparticles in 
cancer therapy: therapeutic efficacy studies of GA-198AuNP nanoconstruct in prostate tumorbearing mice, Nanomedicine: Nanotechnology, Biology and Medicine, 6 (2010) 201-209.

[167] P. Mukherjee, R. Bhattacharya, P. Wang, L. Wang, S. Basu, J.A. Nagy, A. Atala, D. Mukhopadhyay, S. Soker, Antiangiogenic Properties of Gold Nanoparticles, Clinical Cancer Research, 11 (2005) 3530-3534.

[168] E.C. Cho, J. Xie, P.A. Wurm, Y. Xia, Understanding the role of surface charges in cellular adsorption versus internalization by selectively removing gold nanoparticles on the cell surface with a I2/KI etchant, Nano Lett, 9 (2009) 1080-1084.

[169] M. Ferrari, Nanogeometry: beyond drug delivery, Nat Nanotechnol. 2008 Mar;3(3):131-2. doi: 10.1038/nnano.2008.46.

[170] Z.-J. Zhu, P.S. Ghosh, O.R. Miranda, R.W. Vachet, V.M. Rotello, Multiplexed Screening of Cellular Uptake of Gold Nanoparticles Using Laser Desorption/Ionization Mass Spectrometry, Journal of the American Chemical Society, 130 (2008) 14139-14143.

[171] J.F. Hainfeld, F.A. Dilmanian, Z. Zhong, D.N. Slatkin, J.A. Kalef-Ezra, H.M. Smilowitz, Gold nanoparticles enhance the radiation therapy of a murine squamous cell carcinoma, Physics in Medicine and Biology, 55 (2010) 3045.

[172] S.C. Coelho, M. Rangel, M.C. Pereira, M.N. Coelho, G. Ivanova, Structural Characterization of Functionalized Gold Nanoparticles for Drug Delivery in Cancer Therapy: a NMR Based Approach, Physical Chemistry Chemical Physics, (2015).

[173] S.E.A. Gratton, P.A. Ropp, P.D. Pohlhaus, J.C. Luft, V.J. Madden, M.E. Napier, J.M. DeSimone, The effect of particle design on cellular internalization pathways, Proceedings of the National Academy of Sciences, 105 (2008) 11613-11618.

[174] A.S. Thakor, J. Jokerst, C. Zavaleta, T.F. Massoud, S.S. Gambhir, Gold Nanoparticles: A Revival in Precious Metal Administration to Patients, Nano Letters, 11 (2011) 4029-4036.

[175] B.D. Chithrani, A.A. Ghazani, W.C. Chan, Determining the size and shape dependence of gold nanoparticle uptake into mammalian cells, Nano Lett, 6 (2006) 662-668.

[176] A.M. Alkilany, C.J. Murphy, Toxicity and cellular uptake of gold nanoparticles: what we have learned so far?, J Nanopart Res, 12 (2010) 2313-2333.

[177] E. Sadauskas, H. Wallin, M. Stoltenberg, U. Vogel, P. Doering, A. Larsen, G. Danscher, Kupffer cells are central in the removal of nanoparticles from the organism, Particle and Fibre Toxicology, 4 (2007) 10-10.

[178] X.D. Zhang, D. Wu, X. Shen, P.X. Liu, F.Y. Fan, S.J. Fan, In vivo renal clearance, biodistribution, toxicity of gold nanoclusters, Biomaterials, 33 (2012) 4628-4638.

[179] A. Kumar, X. Zhang, X.-J. Liang, Gold nanoparticles: Emerging paradigm for targeted drug delivery system, Biotechnology Advances, 31 (2013) 593-606.

[180] M.S. Muthu, S. Singh, Targeted nanomedicines: effective treatment modalities for cancer, AIDS and brain disorders, Nanomedicine, 4 (2008) 105-118.

[181] K.K. Sandhu, C.M. McIntosh, J.M. Simard, S.W. Smith, V.M. Rotello, Gold NanoparticleMediated Transfection of Mammalian Cells, Bioconjugate Chemistry, 13 (2001) 3-6.

[182] J. Wang, Y. Yue, G. Chen, J. Xia, Protease-promoted drug delivery using peptide-

functionalized gold nanoparticles, Soft Matter, 7 (2011) 7217-7222.

[183] L. Vigderman, E.R. Zubarev, Therapeutic platforms based on gold nanoparticles and their covalent conjugates with drug molecules, Adv Drug Deliv Rev, 18 (2012) 18.

[184] Y.-C. Yeh, B. Creran, V.M. Rotello, Gold nanoparticles: preparation, properties, and applications in bionanotechnology, Nanoscale, 4 (2012) 1871-1880.

[185] X.-Q. Zhang, X. Xu, R. Lam, D. Giljohann, D. Ho, C.A. Mirkin, Strategy for Increasing Drug Solubility and Efficacy through Covalent Attachment to Polyvalent DNA-Nanoparticle Conjugates, ACS Nano, 5 (2011) 6962-6970. 
[186] Y.-J. Gu, J. Cheng, C.W.-Y. Man, W.-T. Wong, S.H. Cheng, Gold-doxorubicin nanoconjugates for overcoming multidrug resistance, Nanomedicine: Nanotechnology, Biology and Medicine, 8 (2012) 204-211.

[187] F. Wang, Y.-C. Wang, S. Dou, M.-H. Xiong, T.-M. Sun, J. Wang, Doxorubicin-Tethered Responsive Gold Nanoparticles Facilitate Intracellular Drug Delivery for Overcoming Multidrug Resistance in Cancer Cells, ACS Nano, 5 (2011) 3679-3692.

[188] D. Bhumkar, H. Joshi, M. Sastry, V. Pokharkar, Chitosan Reduced Gold Nanoparticles as Novel Carriers for Transmucosal Delivery of Insulin, Pharmaceutical Research, 24 (2007) 1415-1426. [189] J. Wen, Y.S.K. Betty, T.R. James, C.W.C. Warren, Nanoparticle-mediated cellular response is size-dependent, Nature Nanotechnology, 3 (2008) 145-150.

[190] B. J., J. J., O.-R. K., S. S, Carbohydrate antigen-nanoparticle conjugates and uses thereof as antimetastatic agents in treating cancer, in, 2005.

[191] S.D. Brown, P. Nativo, J.-A. Smith, D. Stirling, P.R. Edwards, B. Venugopal, D.J. Flint, J.A.

Plumb, D. Graham, N.J. Wheate, Gold Nanoparticles for the Improved Anticancer Drug Delivery of the Active Component of Oxaliplatin, Journal of the American Chemical Society, 132 (2010) 46784684.

[192] S.K. Libutti, G.F. Paciotti, A.A. Byrnes, H.R. Alexander, W.E. Gannon, M. Walker, G.D. Seidel, N. Yuldasheva, L. Tamarkin, Phase I and Pharmacokinetic Studies of CYT-6091, a Novel PEGylated Colloidal Gold-rhTNF Nanomedicine, Clinical Cancer Research, 16 (2010) 6139-6149.

[193] Y. Haba, C. Kojima, A. Harada, T. Ura, H. Horinaka, K. Kono, Preparation of Poly(ethylene glycol)-Modified Poly(amido amine) Dendrimers Encapsulating Gold Nanoparticles and Their HeatGenerating Ability, Langmuir, 23 (2007) 5243-5246.

[194] X. Shi, K. Sun, J.R. Baker, Spontaneous Formation of Functionalized Dendrimer-Stabilized Gold Nanoparticles, The Journal of Physical Chemistry C, 112 (2008) 8251-8258.

[195] M.K. Corbierre, N.S. Cameron, M. Sutton, S.G.J. Mochrie, L.B. Lurio, A. Rühm, R.B. Lennox, Polymer-Stabilized Gold Nanoparticles and Their Incorporation into Polymer Matrices, Journal of the American Chemical Society, 123 (2001) 10411-10412.

[196] R.M. Crooks, M. Zhao, L. Sun, V. Chechik, L.K. Yeung, Dendrimer-Encapsulated Metal Nanoparticles: Synthesis, Characterization, and Applications to Catalysis, Accounts of Chemical Research, 34 (2000) 181-190.

[197] I. Capek, Preparation of metal nanoparticles in water-in-oil (w/o) microemulsions, Advances in Colloid and Interface Science, 110 (2004) 49-74.

[198] S.-H. Park, S.-G. Oh, J.-Y. Mun, S.-S. Han, Loading of gold nanoparticles inside the DPPC bilayers of liposome and their effects on membrane fluidities, Colloids and Surfaces B:

Biointerfaces, 48 (2006) 112-118.

[199] Y.-G. Kim, S.-K. Oh, R.M. Crooks, Preparation and Characterization of 1-2 nm DendrimerEncapsulated Gold Nanoparticles Having Very Narrow Size Distributions, Chemistry of Materials, 16 (2003) 167-172.

[200] P. Nativo, I.A. Prior, M. Brust, Uptake and Intracellular Fate of Surface-Modified Gold Nanoparticles, ACS Nano, 2 (2008) 1639-1644.

[201] D.B. Chithrani, M. Dunne, J. Stewart, C. Allen, D.A. Jaffray, Cellular uptake and transport of gold nanoparticles incorporated in a liposomal carrier, Nanomedicine: Nanotechnology, Biology and Medicine, 6 (2010) 161-169.

[202] L. Paasonen, T. Laaksonen, C. Johans, M. Yliperttula, K. Kontturi, A. Urtti, Gold nanoparticles enable selective light-induced contents release from liposomes, Journal of Controlled Release, 122 (2007) 86-93. 
[203] C.R. Patra, R. Bhattacharya, D. Mukhopadhyay, P. Mukherjee, Fabrication of gold nanoparticles for targeted therapy in pancreatic cancer, Advanced Drug Delivery Reviews, 62 (2010) 346-361.

[204] G.T. Cai Weibo , Hong Hao, Sun Jiangtao, Applications of gold nanoparticles in cancer nanotechnology, Nanotechnology, Science and Applications, 1 (2008) 17-32.

[205] S. Jelveh, D.B. Chithrani, Gold Nanostructures as a Platform for Combinational Therapy in Future Cancer Therapeutics, Cancers, 3 (2011) 1081-1110.

[206] C.v. Sonntag, The chemical basis of radiation biology, Taylor \& Francis, London; Philadelphia, PA, 1989.

[207] K.T. Butterworth, J.A. Coulter, S. Jain, J. Forker, S.J. McMahon, G. Schettino, K.M. Prise, F.J. Currell, D.G. Hirst, Evaluation of cytotoxicity and radiation enhancement using $1.9 \mathrm{~nm}$ gold particles: potential application for cancer therapy, Nanotechnology, 21 (2010) 0957-4484. [208] V. Kattumuri, K. Katti, S. Bhaskaran, E.J. Boote, S.W. Casteel, G.M. Fent, D.J. Robertson, M. Chandrasekhar, R. Kannan, K.V. Katti, Gum arabic as a phytochemical construct for the stabilization of gold nanoparticles: in vivo pharmacokinetics and X-ray-contrast-imaging studies, Small, 3 (2007) 333-341.

[209] E.S. Glazer, C. Zhu, K.L. Massey, C.S. Thompson, W.D. Kaluarachchi, A.N. Hamir, S.A. Curley, Noninvasive radiofrequency field destruction of pancreatic adenocarcinoma xenografts treated with targeted gold nanoparticles, Clin Cancer Res, 16 (2010) 5712-5721.

[210] X. Huang, W. Qian, I.H. El-Sayed, M.A. El-Sayed, The potential use of the enhanced nonlinear properties of gold nanospheres in photothermal cancer therapy, Lasers in surgery and medicine, 39 (2007) 747-753.

[211] W.N. Rahman, N. Bishara, T. Ackerly, C.F. He, P. Jackson, C. Wong, R. Davidson, M. Geso, Enhancement of radiation effects by gold nanoparticles for superficial radiation therapy, Nanomedicine: Nanotechnology, Biology and Medicine, 5 (2009) 136-142.

[212] T. Kong, J. Zeng, X. Wang, X. Yang, J. Yang, S. McQuarrie, A. McEwan, W. Roa, J. Chen, J.Z. Xing, Enhancement of radiation cytotoxicity in breast-cancer cells by localized attachment of gold nanoparticles, Small, 4 (2008) 1537-1543.

[213] J.F. Hainfeld, F.A. Dilmanian, D.N. Slatkin, H.M. Smilowitz, Radiotherapy enhancement with gold nanoparticles, Journal of Pharmacy and Pharmacology, 60 (2008) 977-985.

[214] J.F. Hainfeld, D.N. Slatkin, H.M. Smilowitz, The use of gold nanoparticles to enhance radiotherapy in mice, Phys Med Biol, 49 (2004) N309-315.

[215] S. Nitta, K. Numata, Biopolymer-Based Nanoparticles for Drug/Gene Delivery and Tissue Engineering, International Journal of Molecular Sciences, 14 (2013) 1629-1654.

[216] Y.Y. Yang, Y. Wang, R. Powell, P. Chan, Polymeric core-shell nanoparticles for therapeutics, Clin Exp Pharmacol Physiol, 33 (2006) 557-562.

[217] G. Saravanakumar, D.G. Jo, J.H. Park, Polysaccharide-based nanoparticles: a versatile platform for drug delivery and biomedical imaging, Curr Med Chem, 19 (2012) 3212-3229. [218] F. Alexis, E. Pridgen, L.K. Molnar, O.C. Farokhzad, Factors Affecting the Clearance and Biodistribution of Polymeric Nanoparticles, Molecular Pharmaceutics, 5 (2008) 505-515.

[219] A.V. Kamlesh Shroff, Polymer Nanoparticles: Newer Strategies towards Targeted Cancer Therapy, Journal of Physical Chemistry \& Biophysics, 3 (2013).

[220] J. Panyam, V. Labhasetwar, Biodegradable nanoparticles for drug and gene delivery to cells and tissue, Adv Drug Deliv Rev, 55 (2003) 329-347.

[221] C.-M.J. Hu, S. Aryal, L. Zhang, Nanoparticle-assisted combination therapies for effective cancer treatment, Therapeutic Delivery, 1 (2010) 323-334.

[222] A. Vila, A. Sánchez, M. Tobío, P. Calvo, M.J. Alonso, Design of biodegradable particles for protein delivery, Journal of Controlled Release, 78 (2002) 15-24. 
[223] L. Mu, S.S. Feng, A novel controlled release formulation for the anticancer drug paclitaxel (Taxol): PLGA nanoparticles containing vitamin E TPGS, J Control Release, 86 (2003) 33-48.

[224] R. Duncan, The dawning era of polymer therapeutics, Nat Rev Drug Discov, 2 (2003) 347-360.

[225] N. Goodarzi, R. Varshochian, G. Kamalinia, F. Atyabi, R. Dinarvand, A review of

polysaccharide cytotoxic drug conjugates for cancer therapy, Carbohydrate Polymers, 92 (2013) 1280-1293.

[226] J.W. Singer, R. Bhatt, J. Tulinsky, K.R. Buhler, E. Heasley, P. Klein, P. de Vries, Water-soluble poly-(L-glutamic acid)-Gly-camptothecin conjugates enhance camptothecin stability and efficacy in vivo, J Control Release, 74 (2001) 243-247.

[227] R.R. Arvizo, S. Rana, O.R. Miranda, R. Bhattacharya, V.M. Rotello, P. Mukherjee, Mechanism of anti-angiogenic property of gold nanoparticles: role of nanoparticle size and surface charge, Nanomedicine, 7 (2011) 580-587.

[228] V.R. Sinha, R. Kumria, Polysaccharides in colon-specific drug delivery, International Journal of Pharmaceutics, 224 (2001) 19-38.

[229] M.F. Frasco, G.M. Almeida, F. Santos-Silva, C. Pereira Mdo, M.A. Coelho, Transferrin surfacemodified PLGA nanoparticles-mediated delivery of a proteasome inhibitor to human pancreatic cancer cells, Journal of biomedical materials research. Part A, 103 (2015) 1476-1484.

[230] Z. Liu, Y. Jiao, Y. Wang, C. Zhou, Z. Zhang, Polysaccharides-based nanoparticles as drug delivery systems, Advanced Drug Delivery Reviews, 60 (2008) 1650-1662.

[231] B. Gomes, I. Moreira, S. Rocha, M. Coelho, M.d.C. Pereira, Polysaccharide-Based

Nanoparticles for Cancer Therapy, Journal of Nanopharmaceutics and Drug Delivery, 1 (2013) 335354.

[232] S. Boddohi, N. Moore, P.A. Johnson, M.J. Kipper, Polysaccharide-based polyelectrolyte complex nanoparticles from chitosan, heparin, and hyaluronan, Biomacromolecules, 10 (2009) 1402-1409.

[233] S.A. Agnihotri, N.N. Mallikarjuna, T.M. Aminabhavi, Recent advances on chitosan-based micro- and nanoparticles in drug delivery, Journal of Controlled Release, 100 (2004) 5-28.

[234] K.V. Harish Prashanth, R.N. Tharanathan, Depolymerized products of chitosan as potent inhibitors of tumor-induced angiogenesis, Biochimica et Biophysica Acta, 11 (2005) 22-29.

[235] C.-M. Lehr, J.A. Bouwstra, E.H. Schacht, H.E. Junginger, In vitro evaluation of mucoadhesive properties of chitosan and some other natural polymers, Int. J. Pharm., 78 (1992) 43-48.

[236] K.V. Harish Prashanth, R.N. Tharanathan, Depolymerized products of chitosan as potent inhibitors of tumor-induced angiogenesis, Biochimica et Biophysica Acta (BBA) - General Subjects, 1722 (2005) 22-29.

[237] M.R. Avadi, A.M.M. Sadeghi, N. Mohamadpour Dounighi, R. Dinarvand, F. Atyabi, M. RafieeTehrani, Ex vivo evaluation of insulin nanoparticles using chitosan and arabic gum, 2011.

[238] A.M. Islam, G.O. Phillips, A. Sljivo, M.J. Snowden, P.A. Williams, A review of recent developments on the regulatory, structural and functional aspects of gum arabic, Food Hydrocolloids, 11 (1997) 493-505.

[239] C.-P. Liu, F.-S. Lin, C.-T. Chien, S.-Y. Tseng, C.-W. Luo, C.-H. Chen, J.-K. Chen, F.-G. Tseng, Y. Hwu, L.-W. Lo, C.-S. Yang, S.-Y. Lin, In-situ Formation and Assembly of Gold Nanoparticles by Gum Arabic as Efficient Photothermal Agent for Killing Cancer Cells, Macromolecular Bioscience, (2013) n/a-n/a.

[240] U. Effiong, D. Williams, W. Otto, W. Anderson, Gum Arabic surface-modified magnetic nanoparticles for cancer therapy, in: Bioengineering Conference, 2004. Proceedings of the IEEE 30th Annual Northeast, 2004, pp. 243-244.

[241] M.R. Avadi, A.M.M. Sadeghi, N. Mohammadpour, S. Abedin, F. Atyabi, R. Dinarvand, M. Rafiee-Tehrani, Preparation and characterization of insulin nanoparticles using chitosan and Arabic 
gum with ionic gelation method, Nanomedicine : nanotechnology, biology, and medicine, 6 (2010) 58-63.

[242] W. Sun, S. Mao, D. Mei, T. Kissel, Self-assembled polyelectrolyte nanocomplexes between chitosan derivatives and enoxaparin, European Journal of Pharmaceutics and Biopharmaceutics, 69 (2008) 417-425.

[243] A.V. Il'ina, V.P. Varlamov, Chitosan-based polyelectrolyte complexes: a review, Prikladnaia biokhimiia i mikrobiologiia, 41 (2005) 9-16.

[244] M.J. Ramalho, J.A. Loureiro, B. Gomes, M.F. Frasco, M.A.N. Coelho, M.C. Pereira, PLGA nanoparticles as a platform for vitamin D-based cancer therapy, Beilstein Journal of Nanotechnology, 6 (2015) 1306-1318.

[245] C. Fonseca, S. Simões, R. Gaspar, Paclitaxel-loaded PLGA nanoparticles: preparation, physicochemical characterization and in vitro anti-tumoral activity, Journal of Controlled Release, 83 (2002) 273-286.

[246] H. Yang, K. Li, Y. Liu, Z. Liu, H. Miyoshi, Poly(D, L-lactide-co-glycolide) nanoparticles encapsulated fluorescent isothiocyanate and paclitaxol: preparation, release kinetics and anticancer effect, J Nanosci Nanotechnol, 9 (2009) 282-287.

[247] C.Y.C. Su Young Chae, Mi Kyeong Jang, Teok Rae Jung, Jae-Woon Nah, Anti-cancer agent loaded hydrophobic bile acid conjugated hydrophilic chitosan oligosaccharide nanoparticles and preparation method thereof, in, 2007.

[248] S.K. Sahu, S. Maiti, T.K. Maiti, S.K. Ghosh, P. Pramanik, Hydrophobically modified carboxymethyl chitosan nanoparticles targeted delivery of paclitaxel, J Drug Target, 19 (2011) 104113.

[249] P. Magadala, L. Vlerken, A. Shahiwala, M. Amiji, Multifunctional Polymeric Nanosystems for Tumor-Targeted Delivery, in: V. Torchilin (Ed.) Multifunctional Pharmaceutical Nanocarriers, Springer New York, 2008, pp. 33-66.

[250] H. Maeda, G.Y. Bharate, J. Daruwalla, Polymeric drugs for efficient tumor-targeted drug delivery based on EPR-effect, European Journal of Pharmaceutics and Biopharmaceutics, 71 (2009) 409-419.

[251] J. Lee, M. Twomey, C. Machado, G. Gomez, M. Doshi, A.J. Gesquiere, J.H. Moon, Caveolaemediated endocytosis of conjugated polymer nanoparticles, Macromol Biosci, 13 (2013) 913-920. [252] R. Sinha, G.J. Kim, S. Nie, D.M. Shin, Nanotechnology in cancer therapeutics: bioconjugated nanoparticles for drug delivery, Mol Cancer Ther, 5 (2006) 1909-1917.

[253] S. Coelho, S. Rocha, P. Sampaio, M. Pereira, M.N. Coelho, Encapsulation of a proteasome inhibitor with gold-polysaccharide nanocarriers, Journal of Nanoparticle Research, 16 (2014) 1-10. [254] M. Das, K. Shim, S. An, D. Yi, Review on gold nanoparticles and their applications, Toxicol. Environ. Health Sci., 3 (2011) 193-205.

[255] S. Coelho, S. Moreno-Flores, J.L. Toca-Herrera, M.A. Coelho, M.C. Pereira, S. Rocha, Nanostructure of polysaccharide complexes, J Colloid Interface Sci, 363 (2011) 450-455. 